Review

\title{
Comparison between the Biological Active Compounds in Plants with Adaptogenic Properties (Rhaponticum carthamoides, Lepidium meyenii, Eleutherococcus senticosus and Panax ginseng)
}

\author{
Velislava Todorova *, Kalin Ivanov and Stanislava Ivanova (ID
}

check for updates

Citation: Todorova, V.; Ivanov, K.; Ivanova, S. Comparison between the Biological Active Compounds in Plants with Adaptogenic Properties (Rhaponticum carthamoides, Lepidium meyenii, Eleutherococcus senticosus and Panax ginseng). Plants 2022, 11, 64. https://doi.org/10.3390/

plants11010064

Academic Editors: Laura Cornara and Antonella Smeriglio

Received: 6 December 2021

Accepted: 24 December 2021

Published: 26 December 2021

Publisher's Note: MDPI stays neutral with regard to jurisdictional claims in published maps and institutional affiliations.

Copyright: (C) 2021 by the authors. Licensee MDPI, Basel, Switzerland. This article is an open access article distributed under the terms and conditions of the Creative Commons Attribution (CC BY) license (https:// creativecommons.org/licenses/by/ $4.0 /)$.
Department of Pharmacognosy and Pharmaceutical Chemistry, Faculty of Pharmacy, Medical University-Plovdiv, 4002 Plovdiv, Bulgaria; kalin.ivanov@mu-plovdiv.bg (K.I.); stanislava.ivanova@mu-plovdiv.bg (S.I.)

* Correspondence: velislava.todorova@mu-plovdiv.bg

\begin{abstract}
Background: In the 1960s, research into plant adaptogens began. Plants with adaptogenic properties have rich phytochemical compositions and have been used by humanity since ancient times. However, it is not still clear whether the adaptogenic properties are because of specific compounds or because of the whole plant extracts. The aim of this review is to compare the bioactive compounds in the different parts of these plants. Methods: The search strategy was based on studies related to the isolation of bioactive compounds from Rhaponticum carthamoides, Lepidium meyenii, Eleutherococcus senticosus, and Panax ginseng. The Preferred Reporting Items for Systematic Reviews and Meta-Analyses (PRISMA) guidelines were followed. Results: This review includes data from 259 articles. The phytochemicals isolated from Rhaponticum carthamoides, Lepidium meyenii, Eleutherococcus senticosus, and Panax ginseng were described and classified in several categories. Conclusions: Plant species have always played an important role in drug discovery because their effectiveness is based on the hundreds of years of experience with folk medicine in different nations. In our view, there is great potential in the near future for some of the phytochemicals found in these plants species to become pharmaceutical agents.
\end{abstract}

Keywords: adaptogen; adaptogens; plant adaptogens; Rhaponticum carthamoides; Leuzea; ecdysterone; Lepidium meyenii; Maca; Eleutherococcus senticosus; Panax ginseng

\section{Introduction}

The term adaptogen was introduced for the first time in the 1940s by Dr. Nikolai Lazarev [1]. The classical definition of adaptogens is related to their ability to increase the organism's resistance to stress factors ("stressors") [2,3]. These stressors have different natures: chemical, physical, or other [2,3]. Examples of such stress factors include unfavorable atmospheric temperature, intense physical activity, high-altitude hypoxia, etc. According to the definition, the adaptogens should not only protect the organism from damage from stress situations/factors, but should also not increase the oxygen consumption and not disturb the normal functions of the organism [2]. Adaptogens are also called metabolic regulators [2]. However, the adaptogenic effect is described as "nonspecific" [2].

I. I. Brekhman and I. V. Dardymov are the researchers who first classified the plants with adaptogenic properties: Panax ginseng C. A. Mey., Eleutherococcus senticosus Max. and Rhaponticum carthamoides (Wild.) Iljin from Araliaceae family, Rhodiola rosea L. from Crassulaceae family and Schisandra chinensis from Schisandraceae family are plants with adaptogenic properties [4]. Later, the "family of plant-adaptogens" was expanded to include: Bryonia alba L. (Cucurbitaceae), Tribulus terrestris L. (Zygophyllaceae), Bacopa monnieri L. Pennell (Plantaginaceae), Lepidium meyenii Walp. (Brassicaceae) and Withania somnifera (L.) Dunal (Solanaceae) [3,5-10]. 
Plants with adaptogenic properties have rich phytochemical compositions and different applications [3,11-20]. However, it is not still clear whether the adaptogenic properties are because of specific compounds or because of the whole plant extracts. Studies that compare the biological activities of the different compounds and the whole extracts are limited. There is no study that compares the phytochemical compositions of the most important plant adaptogens.

There is great potential for some of the phytochemicals found in Rhaponticum carthamoides, Lepidium meyenii, Eleutherococcus senticosus and Panax ginseng to become pharmaceutical agents. The aim of this review is to compare the bioactive compounds in the different parts of these plants (roots, leaves, seeds, etc.), which will support the study, evaluation, and extraction of specific molecules from Rhaponticum carthamoides, Lepidium meyenii, Eleutherococcus senticosus, and Panax ginseng.

\section{Materials and Methods}

The search strategy was to seek studies related to the isolation of bioactive compounds from Rhaponticum carthamoides, Lepidium meyenii, Eleutherococcus senticosus, and Panax ginseng and their activities. This was conducted following the Preferred Reporting Items for Systematic Reviews and Meta-Analyses (PRISMA) guidelines, presented in Figure 1. This search was performed using the following databases: PubMed, Sci Finder, and Web of Science.

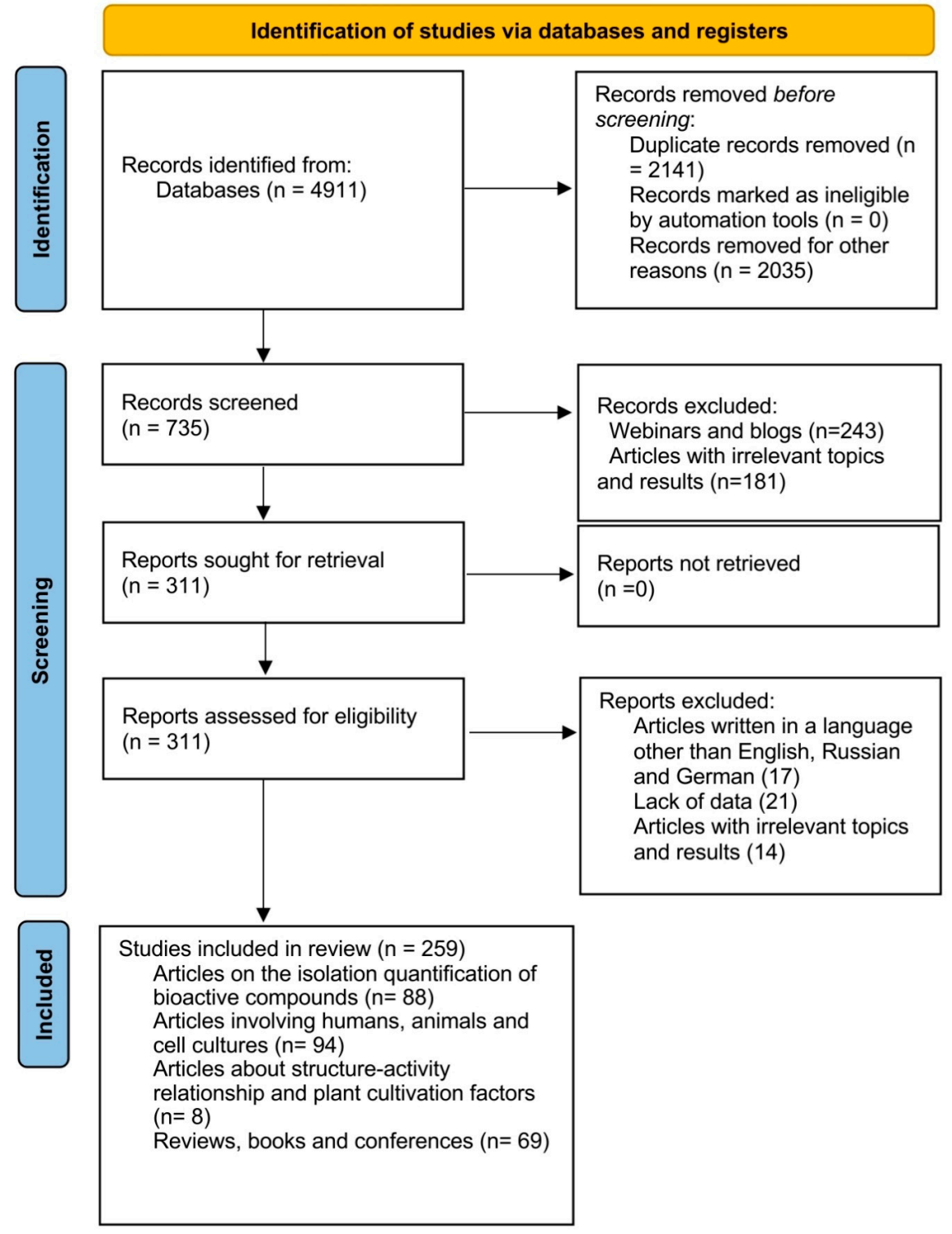

Figure 1. PRISMA 2020 flow diagram [21]. 
The keywords included in the search were: "phytosteroids", "bioactive compounds", "phenolic acids", "flavonoids", "content of ecdysterone", "phytochemicals", "chemical compounds", "Lepidium meyenii", "Eleutherococcus senticosus", "Rhaponticum carthamoides", "Panax ginseng", "Maca root", "ecdysterone", "macamides and macaenes", "polysaccharides", "glucosinolates", "eleutherosides", "ginsenosides", "structure-activity relationship", "animal studies", "human studies" and "cell culture studies".

In the final step, the selected articles were read and identified. In total, 259 studies were selected and included in the present review.

\section{Results and Discussion}

The main phytochemical classes isolated from different plant parts of Rhaponticum carthamoides, Lepidium meyenii, Eleutherococcus senticosus, and Panax ginseng were phytosteroids, phytosterols, flavoloids, flavolignans, alkaloids, glucosinolates, saponins, phenolic acids and others $[12,13,22,23]$. Phytosteroids are the main bioactive compounds isolated from Rhaponticum carthamoides roots, leaves, and seeds, and they are not found in Panax ginseng, Eleutherococcus senticosus, and Lepidium meyenii $[12,13,22,23]$. Flavonoids are also detected in Rhaponticum carthamoides leaves and roots, but they are not detected in Lepidium meyenii, Eleutherococcus senticosus or Panax ginseng plant parts [12,22-26]. Macaenes, macamides, alkaloids, glucosinolates and sterols are isolated from Lepidium meyenii tuber, but are not detected in the other adaptogens, such as Panax ginseng, Eleutherococcus senticosus, and Rhaponticum carthamoides $[12,13,22,23]$. The main phytochemicals isolated from Panax ginseng and Eleutherococcus senticosus are saponins and their glycosides, which are not detected in Rhaponticum carthamoides and Lepidium meyenii [12,13,22,23]. Phenolic acids are detected in Rhaponticum carthamoides roots and Eleutherococcus senticosus roots, but not in Lepidium meyenii and Panax ginseng [22,23,27-29]. The isolated nutritional ingredients differentiate Maca from other plants with adaptogenic properties [12,13,22,23,30]. Maca is the only plant among these that is considered not only a medicinal plant, but also a food.

\subsection{Rhaponticum carthamoides}

Rhaponticum carthamoides (Wild.) Iljin is an endemic plant, naturally grown in South Siberia [13]. Humans have known of the plant since ancient times, and its various applications have been described in Eastern folk medicine [13]. It had been used for the treatment of fever, cardiovascular diseases, fatigue, kidney diseases, reproductive and sexual disfunction, quinsy, etc., [13,31,32].

Rhaponticum carthamoides is a perennial plant [13,31,33]. It can reach up to $150 \mathrm{~cm}$ in height [13]. It is a semi-rosulate plant [31]. The main parts utilized for the production of extracts are roots and rhizomes [13]. Rhaponticum carthamoides rhizome cum radicibus are included in Russian pharmacopoeia [34]. However, the plant is not included in the European, British, or USA pharmacopeias. The rhizome (shown in Figure 2) is dark black, vertical, branched, and wrinkled, and can reach up to $36 \mathrm{~cm}$ in length. The roots are smooth and elastic with numerous branches [34].

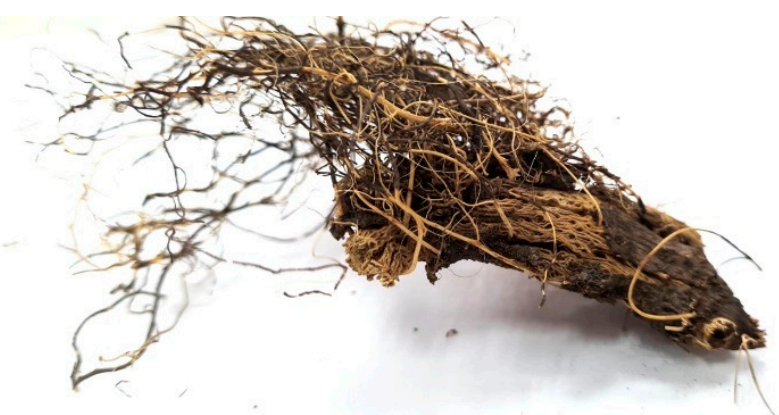

Figure 2. Rhaponticum carthamoides rhizome. 
Nowadays, Rhaponticum carthamoides extract is included in numerous dietary supplements. Its intake is associated with not only adaptogenic activity, but also with antimicrobial, anti-oxidative, neuroprotective, antidiabetic, and anabolic activity $[13,31]$. The intake of Rhapoticum carthamoides extract is not associated with side effects [13,35-38]. The main bioactive compounds detected in Rhaponticum carthamoides are phytosteroids, flavonoids, and phenolic acids. The plant is also a source of essential oil $[13,39,40]$. The plant is a rich source of phytoecdysteroids-a large class of steroid compounds [41,42]. Their structures are composed by 27-29 C-atoms, with a four-ring steroid skeleton [39,42-44] and contain polyhydroxyl groups (4-7 hydroxyl groups) [45]. Nowadays, more than 200 ecdysteroid compounds are described [41,46], 50 of which are isolated from Rhaponthicum carthamoides [13]. These compounds are found in the roots, leaves, and seeds of the plant [47-56]. The content of 20-hydroxyecdysterone, which is the main ecdysteroid, is higher in roots than in leaves and seeds [47-56].

The structure-activity relationship of ecdisteroids is still not well clarified. Some researchers suggest that the presence of hydroxyl groups on C-5, C-14, and C-22 positions is very important for the biological activity of these compounds as well the presence of double bond at C-7 and keto-group at C-6 (example: ecdisterone) [57-59]. The presence of 2,3-diol system, hydroxyl group at C-20 in ecdysteroids structures is important for the anabolic activity [60].

Some of the beneficial effects related to phytoecdysteroids are anabolic, hypocholesterolemetic, neuroprotective, hypoglycemic, and metabolism regulation [60,61]. However, Rhaponthicum carthamoides is not the only source of ecdysteroids. There are other plants that contain 20-hydroxyecdysterone. These are Achyranthes bidentata Blume, Achyranthes japonica (Miq.) Nakai, Ajuga iva (L.) Schreb, Boerhaavia diffusa L. nom. cons., Diploclisia glaucescens (Blume) Diels, Pfaffia glomerata (Spreng.) Pedersen, Spinacia oleracea L., Polypodium japonicum Makino, and some others [62-64].

Since 2020, ecdysterone has been included in the World Anti-doping Agency (WADA) monitoring program [65]. According to different studies in mammals, ecdysterone has a wide variety of pharmacological effects: anabolic, anti-diabetic, anti-inflammatory, cardioprotective, hypolipidemic and others [62,66-70].

However, studies that investigated ecdysterone's activity in humans are limited [36-38,71-73]. There are data about the intake of Rhaponticum carthamoides extract, which contains ecdysterone $[38,71,73]$. The intake of Rhaponticum carthamoides extract is associated with decreased body weight; increased resistance to disease; physical and mental endurance; improvement in cardiac and cognitive functions [35,36,72-74]. Studies that investigate ecdysterone activity in cell cultures are also limited [75-79]. According to data obtained from cell culture studies, ecdysterone has great potential to be used for the treatment of diabetes, breast cancer, Alzheimer's disease, and osteoporosis [75-79].

In the near future, it is highly likely that ecdysterone will become a drug molecule, used for obesity management, reducing fatigue or the management of glucose levels. It is also highly likely to be included in WADA's prohibited list if researchers prove it has the potential to improve athletes' performance. However, its biological activity should be studied in more detail in cell cultures and mammals, and in randomized clinical trials.

Rhaponthicum carthamoides is also a source of flavonoids, which are mainly found in the roots and leaves $[24,25]$. Flavonoids are substances with a phenolic structure, and over 8000 flavonoids are known [80,81]. Flavonoids are divided into the subclasses flavonols, flavones, flavanones, catechins, and their glycosides [25]. The presence of flavonoids in Rhaponticum carthamoides extracts determines the hypolipidemic and antioxidative effects of the extract $[81,82]$. Antioxidant activity is associated with the presence of a large number of hydroxyl groups in flavonoids [83].

The plant is also a source of essential oil $[40,84,85]$, which has antimicrobial, antioxidant, and anti-inflammatory activities $[40,84]$. Table 1 presents the bioactive compounds isolated from different plant parts of Rhaponticum carthamoides. 
Table 1. Rhaponticum carthamoides bioactive compounds.

\begin{tabular}{|c|c|c|}
\hline Biological Active Compound & Plant Part & References \\
\hline \multicolumn{3}{|c|}{ Phytosteroids } \\
\hline \multirow{3}{*}{ 20-Hydroxyecdysone } & Roots & {$[47-52,55,86]$} \\
\hline & Leaves & {$[53,55,87,88]$} \\
\hline & Seeds & {$[53,54,56]$} \\
\hline 20-Hydroxyecdysone 2-acetate & Roots & [50] \\
\hline 20-Hydroxyecdysone 3-acetate & Roots & [50] \\
\hline 20-Hydroxyecdysone 2,3-monoacetonide & Roots & {$[48,49,86]$} \\
\hline 20-Hydroxyecdysone 20,22-monoacetonide & Roots & {$[48,49,86]$} \\
\hline 20-Hydroxyecdysone 2,3;20,22-diacetonide & Roots & {$[48,49]$} \\
\hline 2-Deoxyecdysterone & Roots & [86] \\
\hline 3-epi-20-Hydroxyecdysone & Roots & [49] \\
\hline 5- $\alpha$-20-Hydroxyecdysone & Roots & [49] \\
\hline 22-Oxo-20-Hydroxyecdysone & Roots & [49] \\
\hline Leuzeasterone & Roots & [49] \\
\hline \multirow{2}{*}{ Polypodine B } & Roots & {$[48,49,51,86]$} \\
\hline & Seeds & [54] \\
\hline Polypodin B-22-O-benzoate & Seeds & [56] \\
\hline Polypodine B-20,22-acetonide & Roots & [48] \\
\hline Inokosterone & Roots & {$[50,89]$} \\
\hline Inokosterone 20,22-acetonide & Roots & [50] \\
\hline Integristerone A & Roots & {$[49,50,86]$} \\
\hline Integristeone A 20,22-acetonide & Roots & [50] \\
\hline Integristerone B & Roots & {$[49]$} \\
\hline 14-epi-Ponasterone A 22-glucoside & Roots & [50] \\
\hline 15-Hydroxyponasterone A & Roots & [50] \\
\hline Makisterone & Roots & [51] \\
\hline Makicterone A & Roots & {$[48,49]$} \\
\hline Miakisteronte A & Seeds & {$[90]$} \\
\hline Makisterone C & Roots & {$[49,50]$} \\
\hline 24-epi-Makisterone A & Roots & {$[50]$} \\
\hline 24(28)-Dehydromakisterone A & Roots & {$[50,51,86]$} \\
\hline 24(28)-Denyaromakisterone A & Seeds & [54] \\
\hline 26-Hydroxymakisterone C & Roots & [50] \\
\hline 1-Hydroxymakisterone $\mathrm{C}$ & Roots & [50] \\
\hline (24Z)-29-Hydroxy-24(28)-dehydromakisterone C & Roots & {$[49,50]$} \\
\hline 22-Deoxy-28-hydroxymakisterone C & Roots & {$[50]$} \\
\hline Isovitexirone & Roots & {$[48,49]$} \\
\hline Rhapisterone & Roots & [86] \\
\hline Rhapisterone B & Seeds & [91] \\
\hline Rhapisterone C & Seeds & [92] \\
\hline Rhapisterone D & Seeds & [93] \\
\hline
\end{tabular}


Table 1. Cont.

\begin{tabular}{|c|c|c|}
\hline Biological Active Compound & Plant Part & References \\
\hline Rhapisterone D 20-acetate & Seeds & [90] \\
\hline Kaladasterone & Roots & [45] \\
\hline 5-Deoxykaladasterone & Roots & {$[45,51]$} \\
\hline Munisterone A & Roots & [45] \\
\hline Taxisterone & Roots & [49] \\
\hline Rubrosterone & Roots & [49] \\
\hline Dihydrorubrosterone & Roots & [49] \\
\hline Carthamosterone & Roots & [49-51] \\
\hline Carthamosterone A & Seeds & [54] \\
\hline Ajugasterone C & Roots & {$[45,48-51]$} \\
\hline Amarasterone A & Roots & [50] \\
\hline 24(28)-Dehydroamarasterone B & Roots & [50] \\
\hline Turkesteron & Roots & [50] \\
\hline Poststerone & Roots & [49] \\
\hline Eriodictyol-7- $\beta$-glucopyranoside & Leaves & [24] \\
\hline \multicolumn{3}{|c|}{ Flavonoids } \\
\hline Quercetin 5-O-galactoside & Roots & {$[26]$} \\
\hline Isorhamnetin 5-O-rhamnoside & Roots & [26] \\
\hline Patuletin $3^{\prime}-\beta$-xylofuranoside & Leaves & [25] \\
\hline $\begin{array}{l}\text { 6-Hydroxykaempferol-7-O-(6"-O-acetyl- } \beta \text {-D- } \\
\text { glucopyranoside) }\end{array}$ & Leaves & [24] \\
\hline \multicolumn{3}{|c|}{ Phenolic acids } \\
\hline $\begin{array}{c}\text { Protocatechuic acid } \\
\text { Benzoic acid } \\
\text { o-Hydroxyphenylacetic ac } \\
\text { p-Hydroxyphenylacetic ac } \\
\text { m-Hydroxybenzoic acid } \\
\text { p-Hydroxybenzoic acid } \\
\text { Salicylic acid } \\
\text { Gentisic acid } \\
\text { Elagic acid } \\
\text { Chlorogenic acid } \\
\text { Vanillic acid } \\
\text { o-Coumaric acid } \\
\text { p-Coumaric acid } \\
\text { Synapic acid } \\
\text { Caffeic acid } \\
\text { Ferulic acid } \\
\text { Gallic acid } \\
\text { Syringic acid }\end{array}$ & Roots & [27] \\
\hline \multicolumn{3}{|c|}{ Essential oil-components } \\
\hline Geraniol & $\begin{array}{c}\text { Roots and } \\
\text { leaves }\end{array}$ & [85] \\
\hline$\alpha$-Pinene & Roots & {$[40,84]$} \\
\hline
\end{tabular}


Table 1. Cont.

\begin{tabular}{ccc}
\hline Biological Active Compound & Plant Part & References \\
\hline$\beta$-Pinene & Roots & {$[84]$} \\
\hline Limonene & Roots & {$[40,84]$} \\
\hline$\beta$-Caryophyllene & $\begin{array}{c}\text { Roots and } \\
\text { leaves }\end{array}$ & {$[84,85]$} \\
\hline 13-Norcypera-1(5),11(12)-diene & Roots & {$[40]$} \\
\hline Cyperene & Roots & {$[40,84]$} \\
\hline 2,5,8-Trimethyl-1-naphthol & Roots & {$[40]$} \\
\hline Cadalene & Roots & {$[40]$} \\
\hline Cyclosativene & Roots & {$[40,84]$} \\
\hline$\beta$-Elemene & Roots & {$[40,84]$} \\
\hline
\end{tabular}

\subsubsection{Phytochemical Composition of Rhaponticum carthamoides Roots}

The main compounds found in roots are phytoecdysteroids, flavonoids, phenolic acids, monoterpenes, and sesquiterpenes [26,27,40,45,47-52,55,84,86,89]. Some of the phytoecdysteroids and their derivatives isolated from the roots of Rhaponticum carthamoides include 20-hydroxyecdysone, leuzeasterone, polypodine B, rhapisterone, makisterone, carthamoleusterone, turkesteron, 20-hydroxyecdysone 2-acetate, 20-hydroxyecdysone 2,3, 20,22-diacetonide, 20-hydroxyecdysone 2,3-monoacetonide, 15-hydroxyponasterone A and 14-epi-ponasterone A 22-glucoside. The average concentration of 20-hydroxyecdysone (structure shown in Figure 3), also known as $\beta$-ecdysone, ecdysterone, and polypodine A, is $0.049-1.74 \%[51,54,80]$. The flavonoids detected in Rhaponticum carthamoides roots are quercetin 5-O-galactoside and isorhamnetin 5-O-rhamnose [26]. Moreover, phenolic acids are detected in the roots of Rhaponticum carthamoides [27]. These include benzoic acid, salicylic acid, vanillic acid, chlorogenic acid, caffeic acid and gallic acid [27]. Essential oil is also isolated from Rhaponticum carthamoides roots [40,84,85]. Monoterpenes and sesquiterpenes are the main phytochemical elements of essential oil derived from Rhaponticum carthamoides $[40,84]$. Monoterpenes include $\alpha$-pinene, $\beta$-pinene, geraniol, and limonene $[40,78]$. The isolated sesquiterpenes include $\beta$-caryophyllene, 13-norcypera$1(5), 11(12)$-diene, cyperene at a concentration of $18.2 \%$, cadalene with a concentration of $9.6 \%$, cyclosativene, and $\beta$-elemene [40,84]. The concentrations of extracted essential oil varied from 0.07 to $0.11 \%$ [85]. There are limited studies on the composition of Rhaponticum carthamoides essential oil and its therapeutic effects $[3,40,84,85]$. In near future, studies on essential oil and its bioactivity may increase in number.<smiles>CC(C)(O)CC[C@@H](O)[C@H](O)[C@]1(C)CC[C@]2(O)C3=CC(=O)[C@H]4C[C@@H](O)[C@H](O)C[C@]4(C)[C@H]3CC[C@@]21C</smiles>

Figure 3. Chemical structure of 20-Hydroxyecdysone.

Although the root is the main part used for the preparation of Rhaponthicum carthamoides extracts, other parts of the plant also have a rich phytochemical composition. 


\subsubsection{Phytochemical Composition of Rhaponticum carthamoides Leaves}

The main bioactive compounds discovered in the leaves of Rhaponticum carthamoides are phytoecdysone (20-hydroxyecdysone) and flavonoids (patuletin $3^{\prime}-\beta$-xylofuranoside and 6-hydroxykaempferol-7-O-(6"-O-acetyl- $\beta$-D-glucopyranoside) $)[24,25,53,55,87,88]$. The concentration of 20-hydroxyecdysone in leaves varied from 0.02 to $0.71 \%[53,55,87,88]$.

\subsubsection{Phytochemical Composition of Rhaponticum carthamoides Seeds}

The phytochemicals isolated from the seeds of Rhaponticum carthamoides are phytosteroids and their derivates, such as 20-hydroxyecdysone, polypodine B, polypodine B-22-O-benzoate, makisterone A, 24(28)-dehydromakisterone A, rhapisterone, rhapisterone D 20-acetate, and carthamosterone A [53,54,56,90-93]. The average concentration of ecdysterone discovered in seeds is $0.57 \%[53,56,94]$.

\subsection{Lepidium meyenii}

Lepidium meyenii, known as "Maca", is naturally grown in Peru [89]. Maca has been cultivated for more than 2000 years [18,95]. Humans have utilized the extract for the management of different conditions, such as: menopausal syndrome, impaired fertility, anemia, tuberculosis, and fatigue [95-102]. Nowadays, the plant extract is used as an aphrodisiac, anti-fatigue remedy, neuroprotector, antioxidant, memory enhancer, hormone secretion regulator, etc. $[18,30,96,103-105]$. The antiviral activity of the extract is also wellknown, but its potential should be explored in more detail in the near future. The intake of Maca extract is not associated with serious side effects [101,106-109].

Maca is a perennial plant. Its overground part consists of 12-20 basal frost-hardy leaves forming a rosette, the height of which can reach $20 \mathrm{~cm}[98,110,111]$. Its flowers are whitish with a length of $5 \mathrm{~mm}$ [98]. The fruits are two-celled [98]. The seeds are smooth and reddish with an ovoid shape [98]. The underground part- the tuber-is composed of roots and seedling stems (hypocotyl) [98,110-112]. The tuber color varies from white to purple; its size is usually about $10-14 \mathrm{~cm}$, with different shapes [98,110,111]. The weight of the Maca tuber varies from 1 to $5 \mathrm{~kg}$ [111].

The bioactive compounds detected in Maca are alkaloid-like compounds, macamides, macaenes, glucosinolates, sterols, and polysaccharides $[22,105,111,113]$. Alkaloids are natural compounds containing basic nitrogen atoms [113]. Macamides are bioactive secondary benzylalkylamides [114]. Macaenes and macamides are polyunsaturated fatty acids and their amides [100]. They are isolated only from Maca [115,116]. The well-known bioactivities of macamides and macaenes are antitumor and antioxidant $[113,117]$. Phytosterols are cholesterol-like compounds isolated from plants [118]. They have a steroid structure, containing 28-29 carbon alcohols with a side chain with 9-10 carbon atoms [119]. Sterols decrease the plasma concentration of cholesterol [119]. Polysaccharides are carbohydrates. They consist of monosaccharides linked with glycoside bonds $[113,120,121]$. Polysaccharides are important substances with nutritional value [120,121]. The polysaccharides isolated from Lepidium meyenii correspond to immunomodulatory, anti-oxidant, anti-fatigue, anti-viral, anti-tussive, and anti-tumor effects [120,122]. Glucosinolates are sulfur- and nitrogen-rich organic compounds [123-125]. They are secondary metabolites in plants [125]. They are divided into two groups: aromatic and indolic [126,127]. Glucosinolates provide antitumor, antioxidant and fungitoxic activity [128-130].

Several studies involving animals have investigated the Maca extract's biological activity, and reported some beneficial effects such as improvement of memory and cognitive functions, neuroprotective effects, regulation of sexual hormones and spermatogenesis, antioxidant activity, and improvement of lipide and glucose profiles [131-137]. Studies involving humans are limited. However, the data provided by these trials suggest beneficial effects of Maca extract in postmenopausal women, with the management of sexual functions and mood regulation [138-141].

The compounds isolated from Maca with the greatest potential for use as therapeutic agents are macamides and macaenes. Studies that investigate macamides' and macaenes' 
activity in humans are also limited. However, according to data obtained from animal studies, these compounds have great potential to be used for the treatment of ulcerosis, the management of exercise-induce fatigue, and the management of oxidative stress [142-144]. According to data obtained from cell cultures studies, macaenes and macamides have great potential to be used as antioxidants, anticancer drugs, neuroprotectors, and metabolism and inflammatory regulators $[117,145]$.

Table 2 presents bioactive compounds and nutritional ingredients isolated from different plant parts of Lepidium meyenii.

Table 2. Bioactive compounds in Lepidium meyenii.

\begin{tabular}{|c|c|c|}
\hline Biological Active Compound & Plant Part & References \\
\hline \multicolumn{3}{|c|}{ Sterols } \\
\hline Brassicasteryl acetate & Tuber & [22] \\
\hline Ergosteryl acetate & Tuber & [22] \\
\hline Campesteryl acetate & Tuber & [22] \\
\hline$\Delta 22$-Ergostadienyl acetate & Tuber & [22] \\
\hline Sitosteryl acetate & Tuber & [22] \\
\hline Campesterol & Hypocotyls and Leaves & [146] \\
\hline$\beta$-Sytosterol & Hypocotyls and Leaves & [146] \\
\hline \multicolumn{3}{|c|}{ Glucosinolates } \\
\hline Glucosinolate & Root & [30] \\
\hline Benzyl Glucosinolate (Glucotropaeolin) & $\begin{array}{c}\text { Hypocotyls } \\
\text { Root/Tuber } \\
\text { Fresh hypocotyls; Fresh leaf; } \\
\text { Seed; Sprout; Dry } \\
\text { hypocotyls }\end{array}$ & $\begin{array}{c}{[114,126,147]} \\
{[102,148,149]} \\
{[150]}\end{array}$ \\
\hline Desulfoglucotropaeolin & Root & [148] \\
\hline m-Methoxybenzylglucosinolate & Tuber & {$[102,149]$} \\
\hline $\begin{array}{l}\text { 5-Methylsulfinylpentyt glucosinolate } \\
\text { (glucoalyssin) }\end{array}$ & $\begin{array}{c}\text { Fresh hypocotyls; Fresh leaf; } \\
\text { Seed; Sprout; Dry } \\
\text { hypocotyls }\end{array}$ & [150] \\
\hline $\begin{array}{c}\text { p-Hydroxybenzyl } \\
\text { glucosinolate/4-Hydroxybenzyl glucosinolate } \\
\text { (glucosinalbin) }\end{array}$ & $\begin{array}{l}\text { Fresh hypocotyls; Fresh leaf; } \\
\text { Seed; Sprout; Dry } \\
\text { hypocotyls }\end{array}$ & [150] \\
\hline $\begin{array}{c}\text { p-Hydroxybenzyl } \\
\text { glucosinolate/4-Hydroxybenzyl glucosinolate } \\
\text { (glucosinalbin) }\end{array}$ & Hypocotyls & [126] \\
\hline m-Hydroxybenzyl-glucosinolate & $\begin{array}{l}\text { Fresh hypocotyls; Fresh leaf; } \\
\text { Seed }\end{array}$ & [150] \\
\hline Pent-4-enyl glucosinolate (glucobrassicanapin) & Fresh hypocotyls; Fresh leaf & [150] \\
\hline Indolyl 3-methyl glucosinolate (glucobrassicin) & $\begin{array}{l}\text { Fresh hypocotyls; Fresh leaf; } \\
\text { Dry hypocotyls }\end{array}$ & [150] \\
\hline p-Methoxybenzylglucosinolate & $\begin{array}{l}\text { Fresh hypocotyls; Fresh leaf; } \\
\text { Sprout; Dry hypocotyls }\end{array}$ & [150] \\
\hline $\begin{array}{l}\text { 4-Methoxyindolyl-3-methyl glucosinolate } \\
\text { (4-methoxyglucobrassicin) }\end{array}$ & $\begin{array}{l}\text { Fresh hypocotyls; Fresh leaf; } \\
\text { Seed }\end{array}$ & [150] \\
\hline $\begin{array}{l}\text { 4-Methoxyindolyl-3-methyl glucosinolate } \\
\text { (4-methoxyglucobrassicin) }\end{array}$ & Hypocotyls & [126] \\
\hline $\begin{array}{l}\text { 4-Hydroxy-3-indolylmethyl glucosinolate } \\
\text { (4-Hydroxyglucobrassicin) }\end{array}$ & Hypocotyls & [126] \\
\hline
\end{tabular}


Table 2. Cont.

\begin{tabular}{|c|c|c|}
\hline Biological Active Compound & Plant Part & References \\
\hline $\begin{array}{l}\text { 3-Methoxybenzyl glucosinolate } \\
\text { (Glucolimnanthin) }\end{array}$ & Hypocotyls & [126] \\
\hline $\begin{array}{l}\text { 5-Methylsulfinylpentyl glucosinolate } \\
\text { (Glucoalyssin) }\end{array}$ & Hypocotyls & [126] \\
\hline \multicolumn{3}{|c|}{ Alkaloids } \\
\hline Total Alkaloids & $\begin{array}{c}\text { Root } \\
\text { Hypocotyls }\end{array}$ & $\begin{array}{c}{[30]} \\
{[147]}\end{array}$ \\
\hline \multicolumn{3}{|c|}{ Imidazole alkaloids } \\
\hline $\begin{array}{c}\text { Lepidiline A } \\
\text { (1,3-dibenzyl-4,5-dimethylimidazolium chloride) }\end{array}$ & Root & [151] \\
\hline $\begin{array}{c}\text { Lepidiline B } \\
\text { (1,3-dibenzyl-2,4,5-trimethylimidazolium } \\
\text { chloride) }\end{array}$ & Root & {$[148,151]$} \\
\hline \multicolumn{3}{|c|}{ Pyrrole alkaloids } \\
\hline Macapyrrolins A & Root & [123] \\
\hline Macapyrrolins B & Root & [123] \\
\hline Macapyrrolins C & Root & [123] \\
\hline \multicolumn{3}{|c|}{ Macamides } \\
\hline \multirow{2}{*}{ Macamides (benzylalkamides) } & Root/Tuber & {$[30,97]$} \\
\hline & Hypocotyls & [114] \\
\hline \multirow{2}{*}{ Total macamides } & Hypocotyls & [115] \\
\hline & Hypocotyls and Leaves & [146] \\
\hline$N$-benzylhexadecanamide & Hypocotyls & {$[104,115,147]$} \\
\hline N-benzyl-(9Z)-octadecanamide & Hypocotyls & {$[104,115]$} \\
\hline $\begin{array}{l}\text { Methoxy-N-benzyl-(9Z,12Z)- } \\
\text { octadecadienamide }\end{array}$ & Hypocotyls & [104] \\
\hline$N$-benzyloctadecanamide & Hypocotyls & {$[104,115]$} \\
\hline$N$-Benzylhexadecanamide & $\begin{array}{l}\text { Hypocotyls } \\
\text { Tuber }\end{array}$ & $\begin{array}{c}{[115]} \\
{[97]}\end{array}$ \\
\hline N-benzyl-(9Z,12Z)-octadecadienamide & Hypocotyls & {$[104,115]$} \\
\hline N-benzyl-(9Z,12Z,15Z)-octadecatrienamide & Hypocotyls & {$[104,115]$} \\
\hline $\begin{array}{l}\text { Methoxy-N-benzyl-(9Z,12Z,15Z)- } \\
\text { octadecatrienamide }\end{array}$ & Hypocotyls & [104] \\
\hline N-benzyl-5-oxo-6E,8E-octadecadienamide & Tuber & [97] \\
\hline Makamide 1 ( $N$-benzyl palmitamide) & Hypocotyls and Leaves & [146] \\
\hline $\begin{array}{l}\text { Makamide } 2 \text { (N-benzyl-5-oxo-6E, } \\
\text { 8E-octadecadienamide) }\end{array}$ & Hypocotyls and Leaves & [146] \\
\hline $\begin{array}{l}\text { Macaridine (benzylated derivative of } \\
\text { 1,2-dihydro- } N \text {-hydroxypyridine) }\end{array}$ & Tuber & [97] \\
\hline
\end{tabular}


Table 2. Cont.

\begin{tabular}{|c|c|c|}
\hline Biological Active Compound & Plant Part & References \\
\hline \multicolumn{3}{|c|}{ Makaenes } \\
\hline Makaene (5-oxo-6E,8E-octadecadienoic acid) & Tuber & [97] \\
\hline Makaene (5-oxo-6E, 8E-octadecadienoic acid) & Hypocotyls and Leaves & [146] \\
\hline \multicolumn{3}{|c|}{ Flavolignans } \\
\hline $\begin{array}{c}\text { Tricin } 4^{\prime}-O \\
\text { [threo- } \beta \text {-guaiacyl-(7"-O-methyl)-glyceryl] ether }\end{array}$ & Root & [148] \\
\hline Tricin 4'-O-(erythro- $\beta$-guaiacyl-glyceryl) ether & Root & [148] \\
\hline \multicolumn{3}{|c|}{ Others } \\
\hline Alkamides & Tuber & [103] \\
\hline Total Phenols & Hypocotyls and Leaves & [146] \\
\hline Benzylamine & Hypocotyls & [114] \\
\hline Tricin & Root & [148] \\
\hline Pinoresinol & Root & {$[148]$} \\
\hline 4-Hydroxycinnamic acid & Root & [148] \\
\hline Guanosine & Root & [148] \\
\hline 3-Hydroxybenzylisothiocyanate & Root & [148] \\
\hline 5-(Hydroxymethyl)-2-furfural & Root & {$[148]$} \\
\hline Vanillic acid 4-O- $\beta$-D-glucoside & Root & [148] \\
\hline Malic acid & Tuber & [102] \\
\hline Malic acid benzoate & Root & [148] \\
\hline Benzoyl derivative of malic acid & Tuber & [102] \\
\hline Uridine acid & Tuber & [102] \\
\hline Benzoyl derivates of uridine acid & Tuber & [102] \\
\hline $\begin{array}{c}\text { (1R,3S)-1-Methyltetrahydro- } \beta \text {-carboline-3- } \\
\text { carboxylic } \\
\text { acid }\end{array}$ & Tuber & [102] \\
\hline Benzylisothiocyanate & $\begin{array}{c}\text { Tuber } \\
\text { Hypocotyls }\end{array}$ & $\begin{array}{l}{[102]} \\
{[114]}\end{array}$ \\
\hline Polysaccharide MC-1 & Root & {$[127,152]$} \\
\hline
\end{tabular}

\subsubsection{Phytochemicals Isolated from Maca Root}

The main compounds isolated form this part of the plant are the macamides, imidazole alkaloids, pyrrole alkaloids, glucosinolates, flavolignans, polysaccharides, and others $[30,123,127,148,151]$. The main imidazole alkaloids detected in Maca root are lepidiline A and lepidiline B [148,151]. Macapyrrolins A, macapyrrolins B and macapyrrolins C are the pyrrole alkaloids detected in Maca root [123]. Glucotropaeolins, known as benzylglucosinolate and desulfoglucotropaeolin are the glucosinolates isolated from Maca root [148]. The flavolignans detected in Maca root are tricin $4^{\prime}-O$ [threo- $\beta$-guaiacyl-( $7^{\prime \prime}-O$-methyl)glyceryl] ether and tricin $4^{\prime}-O$-(erythro- $\beta$-guaiacyl-glyceryl) ether [148]. The polysaccharide MC-1 contains the following monosaccharides (with the given concentrations): arabinose$26.21 \%$, mannose $-11.81 \%$, galactose $-8.32 \%$ and glucose $-53.66 \%$ [127].

\subsubsection{Bioactive Compounds Detected in Lepidium meyenii Tuber}

The Lepidium meyenii tuber contains sterols, glucosinolates, macamides, macaenes, alkamides, and others $[22,97,102,103,149]$. Brassicasteryl acetate, ergosteryl acetate, campesteryl acetate, $\Delta 22$-ergostadienyl acetate, and sitosteryl acetate are sterols isolated from the Lepid- 
ium meyenii tuber [22]. Benzylglucosinolate and its derivate m-methoxybenzylglucosinolate are also isolated $[95,143]$. The alkamides discovered in tuber Lepidium meyenii are $N$-benzyl9-oxo-12Z-octadecenamide, N-benzyl-9-oxo-12Z,15Z-octadecadienamide, $N$-benzyl-15Ztetracosenamide, $N$-(m-methoxybenzyl) hexadecanamide and N-benzyl-13-oxo-9E,11Eoctadecadienamide [103].

\subsubsection{Bioactive Compounds Isolated from Lepidium meyenii Hypocotyls}

The hypocotyls are rich in benzylamine, benzyl glucosinolates, and their derivates, alkaloids, macamides, sterols, and phenols [104,114,115,126,146,147,150]. Some of the isolated glucosinolates and their derivatives include benzyl glucosinolate, glucoalyssin, glucosinlbin, glucobrassicin and glucobrassicanapin [150]. Some of the detected macamides are $N$ benzylhexadecaanamide, $N$-benzyloctadecanamide, $N$-benzyl-(9Z,12Z)-octadecadienamide, $N$-benzyl-(9Z,12Z,15Z)-octadecatrienamide, and methoxy-N-benzyl-(9Z,12Z,15Z)-octadeca trienamide $[104,115,147]$. The concentration of total macamides varies from 0.0016 to $0.0123 \%$ [109] Sterols isolated from Maca hypocotyls include campesterol and $\beta$-sytosterol; their structures are shown in Figure 4 [146].

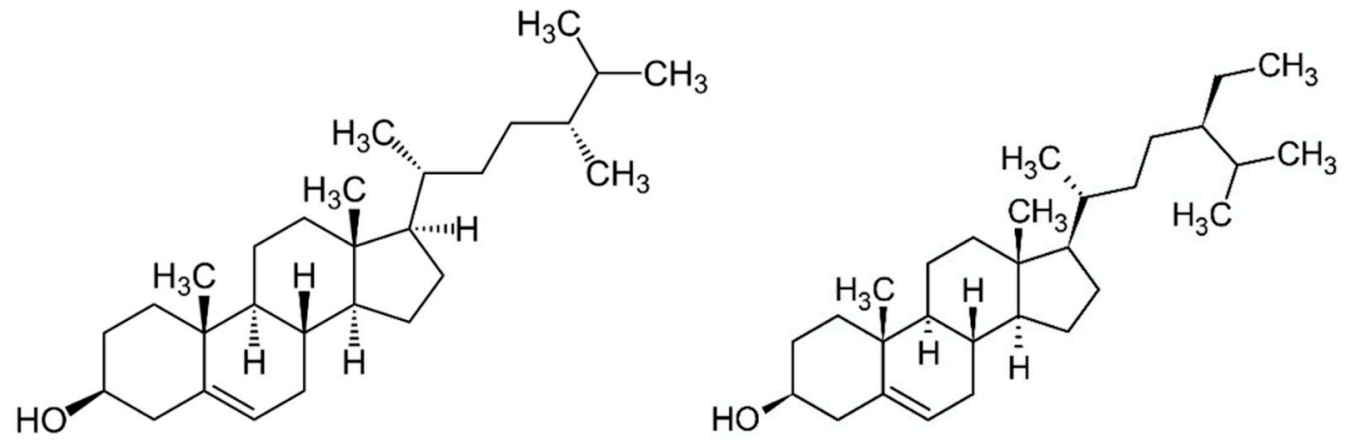

\section{Campesterol}

$\beta$-Sytosterol

Figure 4. Structures of Campesterol and $\beta$-Sytosterol.

\subsubsection{Nutritional Ingredients Isolated from Maca}

Lepidium meyenii contains some essential nutrients, such as amino acids, fibers, fatty acids, lipids, proteins, and minerals [18,22]. Because of its unique nutritional and phytochemical composition, Maca is considered a "super food" [95,111,153]. Different Maca extracts, such as the tuber and starch, are used as food [154-156]. The term "super foods" includes products that are used as foods and medicine, which are edible [153]. In the last few decades, research into superfoods has increased [157]. Super foods may contain chemical-free proteins, amino acids, fatty acids, vitamins, minerals, polysaccharides, and other natural ingredients [158]. The intake of super foods provides essential nutrients and antioxidants, and it also supports the immune system, the endocrine system, and the cardiovascular system [159]. The most important nutrients from in Lepidium meyenii are described in Table 3.

The nutritional ingredients isolated from Lepidium meyenii's roots/tuber and its hypocotyls are: proteins, oil, amino acids, fatty acids, and minerals [22,30,114]. The protein concentrations in roots and tubers varied from 10.2 to $13.42 \%$ [22,30], and the content of oil in the tuber is $1.42 \%$ [30]. The lipids concentration in the tuber is $2.2 \%$, the concentration of hydrolysable carbohydrates is $59 \%$, and the concentration of fibers is $8.5 \%$ [22]. The concentration of proteins in hypocotyls varied from 9.31 to $21.02 \%$, and that in fibers varied from 17.82 to $26 \%$ [147]. The essential amino acids discovered in Maca root/tuber and hypocotyls are histidine, threonine, phenylalanine, D-phenylalanine, valin, methionine, isoleucine, leucine and lysine [22,30,155]. Non-essential amino acids isolated from Maca roots include aspartic acid, glutamic acid, serine, glycine, cysteine, alanine, arginine, tyrosine and proline [22,30,155]. Fatty acids such as lauric, C13:1 tridecanoic, myristic, palmitoleic, palmitic, linoleic, oleic, stearic, arachidic, behenic, lignoceric and nervonic are 
isolated from Maca root/tuber and hypocotyls [114]. The main detected minerals are Fe, $\mathrm{Mn}, \mathrm{Cu}, \mathrm{Na}, \mathrm{K}, \mathrm{Ca}, \mathrm{Mg}$, and $\mathrm{Zn}[22,30,155]$.

Table 3. Nutritional ingredients in Lepidium meyenii.

\begin{tabular}{|c|c|c|}
\hline Nutritional Ingredient & Plant Part & References \\
\hline Proteins & $\begin{array}{l}\text { Root/Tuber } \\
\text { Hypocotyls }\end{array}$ & $\begin{array}{c}{[22,30]} \\
{[147]}\end{array}$ \\
\hline Oil & Root & [30] \\
\hline Lipids & Tuber & [22] \\
\hline Hydrolyzable carbohydrates & Tuber & [22] \\
\hline Whole fibre & Tuber & [22] \\
\hline Total dietary fibre & Hypocotyls & [147] \\
\hline Amino acids & Root/Tuber & {$[22,30]$} \\
\hline \multirow{2}{*}{ Aspartic acid } & Root/Tuber & {$[22,30]$} \\
\hline & Hypocotyls & [147] \\
\hline \multirow{2}{*}{ Glutamic acid } & Root/Tuber & {$[22,30]$} \\
\hline & Hypocotyls & [147] \\
\hline \multirow{2}{*}{ Serine } & Root/Tuber & {$[22,30]$} \\
\hline & Hypocotyls & [147] \\
\hline \multirow{2}{*}{ Glycine } & Root/Tuber & {$[22,30]$} \\
\hline & Hypocotyls & [147] \\
\hline \multirow{2}{*}{ Cysteine } & Root/Tuber & {$[22,30]$} \\
\hline & Hypocotyls & [147] \\
\hline \multirow{2}{*}{ Alanine } & Root/Tuber & {$[22,30]$} \\
\hline & Hypocotyls & [147] \\
\hline \multirow{2}{*}{ Arginine } & Root/Tuber & {$[22,30]$} \\
\hline & Hypocotyls & [147] \\
\hline \multirow{2}{*}{ Tyrosine } & Root/Tuber & {$[22,30]$} \\
\hline & Hypocotyls & [147] \\
\hline Hydroxy-Proline & Tuber & [22] \\
\hline \multirow{2}{*}{ Proline } & Root/Tuber & {$[22,30]$} \\
\hline & Hypocotyls & [147] \\
\hline \multirow{2}{*}{ Histidine } & Root/Tuber & {$[22,30]$} \\
\hline & Hypocotyls & [147] \\
\hline \multirow{2}{*}{ Threonine } & Root/Tuber & {$[22,30]$} \\
\hline & Hypocotyls & [147] \\
\hline Phenylalanine & $\begin{array}{l}\text { Root/Tuber } \\
\text { Hypocotyls }\end{array}$ & $\begin{array}{c}{[22,30]} \\
{[147]}\end{array}$ \\
\hline D-phenylalanine & Root & [148] \\
\hline Valine & $\begin{array}{l}\text { Root/Tuber } \\
\text { Hypocotyls }\end{array}$ & $\begin{array}{c}{[22,30]} \\
{[147]}\end{array}$ \\
\hline Methionine & $\begin{array}{l}\text { Root/Tuber } \\
\text { Hypocotyls }\end{array}$ & $\begin{array}{c}{[22,30]} \\
{[147]}\end{array}$ \\
\hline
\end{tabular}


Table 3. Cont.

\begin{tabular}{|c|c|c|}
\hline Nutritional Ingredient & Plant Part & References \\
\hline \multirow{2}{*}{ Isoleucine } & Root/Tuber & {$[22,30]$} \\
\hline & Hypocotyls & {$[147]$} \\
\hline \multirow{2}{*}{ Leucine } & Root/Tuber & {$[22,30]$} \\
\hline & Hypocotyls & [147] \\
\hline \multirow{2}{*}{ Lysine } & Root/Tuber & {$[22,30]$} \\
\hline & Hypocotyls & {$[147]$} \\
\hline Tryptophan & Tuber & [22] \\
\hline Sarcosine & Tuber & [22] \\
\hline Fatty acids & Root/Tuber & {$[22,114]$} \\
\hline C12: 0 dodecanoic (lauric) & Tuber & {$[22]$} \\
\hline C13:0 tridecanoic & Tuber & [22] \\
\hline C13:1 7-tridecenoic & Tuber & [22] \\
\hline C14:0 tetradecanoic (myristic) & Tuber & [22] \\
\hline C15:0 pentadecanoic & Tuber & [22] \\
\hline C15:1 7-pentadecenoic & Tuber & [22] \\
\hline Cl6:0 esadecanoic (palmitic) & Tuber & [22] \\
\hline $\begin{array}{l}\text { C16:1 9-esadecenoic } \\
\text { (palmitoleic) }\end{array}$ & Tuber & [22] \\
\hline C17:0 heptadecanoic & Tuber & [22] \\
\hline C17: 19-heptadecenoic & Tuber & [22] \\
\hline C18:0 octadecanoic (stearic) & Tuber & [22] \\
\hline C18:1 9-octadecenoic (oleic) & Tuber & [22] \\
\hline C18: 29,12 -octadecadienoic & Root/Tuber & {$[22,114]$} \\
\hline (linoleic) & Hypocotyls & [104] \\
\hline C19:1 11-nonadecenoic & Tuber & [22] \\
\hline C19:0 nonadecanoic & Tuber & [22] \\
\hline C20: 115-eicosenoic & Tuber & [22] \\
\hline C20:0 eicosanoic (arachidic) & Tuber & [22] \\
\hline C22:0 docosanoic (behenic) & Tuber & [22] \\
\hline $\begin{array}{c}\text { C24:0 tetracosanoic } \\
\text { (lignoceric) }\end{array}$ & Tuber & [22] \\
\hline $\begin{array}{c}\text { C24:1 } 15 \text {-tetracosenoic } \\
\text { (nervonic) }\end{array}$ & Tuber & [22] \\
\hline \multirow{2}{*}{ Linolenic acid } & Hypocotyls & [104] \\
\hline & Root & [114] \\
\hline \multirow{2}{*}{ Minerals } & Root/Tuber & {$[22,30]$} \\
\hline & Hypocotyls & [147] \\
\hline \multirow{2}{*}{$\mathrm{Fe}$} & Root/Tuber & {$[22,30]$} \\
\hline & Hypocotyls & [147] \\
\hline \multirow{2}{*}{ Mn } & Root/Tuber & {$[22,30]$} \\
\hline & Hypocotyls & [147] \\
\hline \multirow{2}{*}{$\mathrm{Cu}$} & Root/Tuber & {$[22,30]$} \\
\hline & Hypocotyls & [147] \\
\hline
\end{tabular}


Table 3. Cont.

\begin{tabular}{clc}
\hline Nutritional Ingredient & Plant Part & References \\
\hline \multirow{2}{*}{$\mathrm{Na}$} & Root/Tuber & {$[22,30]$} \\
& Hypocotyls & {$[147]$} \\
\hline \multirow{2}{*}{$\mathrm{K}$} & Root/Tuber & {$[22,30]$} \\
& Hypocotyls & {$[147]$} \\
\hline \multirow{2}{*}{$\mathrm{Ca}$} & Root/Tuber & {$[22,30]$} \\
& Hypocotyls & {$[147]$} \\
\hline \multirow{2}{*}{$\mathrm{Mg}$} & Root & {$[30]$} \\
& Hypocotyls & {$[147]$} \\
\hline \multirow{2}{*}{$\mathrm{Zn}$} & Root/Tuber & {$[22,30]$} \\
& Hypocotyls & {$[147]$} \\
\hline
\end{tabular}

\subsection{Eleutherococcus senticosus}

Eleutherococcus senticosus (Araliaceae) is a small, woody shrub, known also as "Siberian ginseng", which naturally grows in East Russia, Korea, China, and Japan [12,160]. It is a perennial plant and an important herb in Eastern folk medicine [12,161].

Nowadays, Eleutherococcus senticosus rhizome and radices are also considered especially valuable, and are included in the European and Russian pharmacopoeias [34,162].

The knotty Eleutherococcus senticosus rhizome has a diameter of $4.0 \mathrm{~cm}$ with an irregular cylindrical shape. The bark thickness is $2 \mathrm{~mm}$ with a greyish brown to blackish-brown color. The roots can be up to $15 \mathrm{~cm}$ in length with a diameter of 0.3 to $1.5 \mathrm{~cm}$ [162].

The intake of Eleutherococcus senticosus extract is associated with antioxidant, antiinflammatory, adaptogenic, antidiabetic, and choleretic effects [12,160,163-165]. The most well-known activities of Eleutherococus senticosus are immunoregulation, hepatoprotection, antiviral, and antibacterial effects [12,160,163-165]. The intake of this extract is not associated with adverse effects [35,166-168].

The phytochemicals of Eleutherococcus senticosus roots are composed of phenylpropanoids, saponins, coumarins, lignans, polysaccharides, phenolic acids, and provitamins $[164,165,169]$. Saponins are natural compounds that contain an isoprenoidal-derived aglycone linked with sugar [170]. Eleutherosides provide anti-fatigue, anti-stress, anti-inflammatory, and heartprotective effects [171,172]. Coumarins are phenolic derivates with antioxidant, anti-HIV, spasmolytic, and vasodilating activity $[124,125,173]$. The main effect of polysaccharides is immunostimulation [169,174].

Although all parts of this plant have rich phytochemical compositions, the roots are the most utilized. Roots are used in the form of liquid extracts, powders, etc. [160,175]. According to data from human studies, Eleutherococcus senticosus extract has the potential to improve oxygen consumption, mental health, lipid, and glycemic profile $[167,168,176,177]$. Data obtained from animal studies suggests antidiabetic, antifatigue, neuroprotective, and nootropic activity $[171,172,178,179]$.

The molecules isolated from Eleutherococcus senticosus with the greatest potential to become novel drug molecules are Eleutheroside B and Eleutheroside E.

Studies investigating Eleutheroside B and Eleutheroside E activity in humans are limited. However, according to data obtained from animal studies, they have great potential to be used for the treatment of inflammation, cancer, osteoporosis, and diabetes [172,180-184]. Studies investigating Eleutheroside B and Eleutheroside E activity in cell cultures are sparse [185]. According to data obtained from cell culture studies, they have great potential to be used for the treatment of cardiovascular diseases [185].

Table 4 shows the bioactive compounds isolated from different plant parts of Eleutherococcus senticosus. 
Table 4. Bioactive compounds in Eleutherococcus senticosus.

\begin{tabular}{|c|c|c|}
\hline Biological Active Compound & Plant Part & References \\
\hline \multicolumn{3}{|c|}{ Saponins and their glycosides } \\
\hline Eleutheroside A & Roots & [186] \\
\hline Eleutheroside B (syringine) & $\begin{array}{l}\text { Stem } \\
\text { Roots }\end{array}$ & $\begin{array}{c}{[187]} \\
{[28,29,187-189]}\end{array}$ \\
\hline Eleutheroside B1 (isofraxidine glucoside) & Roots & {$[28,29,186]$} \\
\hline Isofraxidine-aglykone of Eleutheroside B1 & Roots & {$[28,29]$} \\
\hline Eleutheroside C & Roots & [186] \\
\hline Eleutheroside D (syringaresinol diglucoside) & Roots & [29] \\
\hline $\begin{array}{c}\text { Eleutheroside E } \\
\text { ((-)syringaresinoldiglucoside) }\end{array}$ & $\begin{array}{l}\text { Stem } \\
\text { Roots }\end{array}$ & $\begin{array}{c}{[187]} \\
{[28,187,188]}\end{array}$ \\
\hline $\begin{array}{l}\text { Eleutheroside E (syringaresinol } \\
\text { di-O- } \beta \text {-D-glucoside; liriodendrin) }\end{array}$ & Roots & [189] \\
\hline Eleutheroside E2 & Roots & [190] \\
\hline Syringaresinol (aglykone of Eleutherosde E) & Roots & {$[28,29]$} \\
\hline Eleutherans A, B, C, D, E, F, G & Roots & [191] \\
\hline \multicolumn{3}{|c|}{ Phenolic acids } \\
\hline Chlorogenic acid & Roots & {$[28,29]$} \\
\hline p-Hydroxybenzoic acid & Roots & [29] \\
\hline Vanillic acid & Roots & [29] \\
\hline Syringic acid & Roots & [29] \\
\hline p-Coumaric acid & Roots & [29] \\
\hline Caffeic acid & Roots & [29] \\
\hline Ethyl ester of caffeic acid & Roots & [28] \\
\hline Ferulic acid & Roots & [29] \\
\hline \multicolumn{3}{|c|}{ Triterpene glycosides } \\
\hline Inermoside & Leaves & [192] \\
\hline 1-Deoxychiisanoside & Leaves & [192] \\
\hline 24-Hydroxychiisanoside & Leaves & [192] \\
\hline 11-Deoxyisochiisanoside & Leaves & [192] \\
\hline \multicolumn{3}{|c|}{ Others } \\
\hline Chiisanoside & Leaves & [193] \\
\hline Chiisanogenin & Leaves & [193] \\
\hline Hyperin & Leaves & [193] \\
\hline Isomaltol 3-O-alpha-D-glucopyranoside & Roots & [190] \\
\hline (-) Sesamine & Roots & {$[28,194]$} \\
\hline Sytoterole & Roots & {$[28]$} \\
\hline Coniferine & Roots & [29] \\
\hline Coniferylaldehyde & Roots & [28] \\
\hline Coniferyl alcohol & Roots & [29] \\
\hline Cumarine & Roots & {$[28]$} \\
\hline Oleanolic acid & Roots & [28] \\
\hline Polysaccharides & Roots & [174] \\
\hline
\end{tabular}




\subsubsection{Phytochemical Compounds Isolated from Eleutherococcus senticosus Roots}

The main detected compounds are saponins and their glycosides, polysaccharides, phenolic acids, and others $[28,29,174,186-191,194]$. Saponins and their glycosides isolated from Eleutherococcus senticosus include eleutheroside A, eleutheroside B (chemical structure shown in Figure 5) with an average concentration $0.045 \%$, eleutheroside $C$, eleutheroside D, eleutheroside $\mathrm{E}$ with an average concentration of $0.056 \%$, eleutheroside $\mathrm{F}$ and eleutheroside $\mathrm{G}[28,29,186-191]$. The identified phenolic acids are chlorogenic, $\mathrm{p}$-hydroxybenzoic, $\mathrm{p}$ coumaric, caffeic, vanillic, and ferulic acid [28,29]. Sesamin (lignan), sytosterole (sterole) and cumarine are also isolated $[28,29,194]$.<smiles>COc1cc(/C=C/CO)cc(OC)c1O[C@H]1O[C@H](CO)[C@@H](O)[C@H](O)[C@H]1O</smiles>

Figure 5. Structure of Eleutheroside B (syringine).

\subsubsection{Phytochemicals Isolated from Eleutherococcus senticosus Stem and Leaves}

The main bioactive compounds are eleutheroside B, with an average concentration of $0.1203 \%$, and eleutheroside E, with an average concentration of $0.085 \%$ [187]. Chiisanoside, hyperin, and triterpene glycosides, such as inermoside, 24-hydroxychiisanoside and 11deoxyisochiisanoside, are the main phytochemical compounds isolated from Eleutherococcus senticosus leaves [192,193].

\subsection{Panax ginseng}

Panax ginseng has always been considered an important medicinal plant. Initially, it was an important part of Eastern folk medicine, and nowadays it is an essential pharmacopeial plant. Furthermore, in the past it was considered the most valuable of all medicinal herbs for the people of Korea, China, and Japan [195].

Brekhman was among the first researchers to introduce the novel pharmacological concept of the tonic effect of ginseng, resulting in the association of the plant with adaptogen effects [195].

Brekhman found out ginseng intake can increase non-specific resistance to various pathological or stress factors. According to his findings, the adaptogenic effect lasts for a long time, and work better under abnormal conditions (stress factors) $[4,195,196]$.

Panax ginseng naturally grows in Korea and China [197,198]. The genus name "Panax" originates from Greek. The word is composed of the words "pan", which means "all", and "axos", which means "treat". The literal translation is "cure all diseases", "cure everything" or "appropriate for treatment of every condition" [195]. The word "ginseng" has an Eastern origin [195].

It is a perennial, self-pollinating plant. It has one stalk and palmate leaves at its end. The flowering starts in its third-year growth stage. Panax ginseng seeds are obtained from plants no less than four years old. Panax ginseng roots may be white or pale yellow, and grow upright. There is one stout primary root and two or five rootlets and root hairs. The size and shape of the rootlets depends on water content, soil quality, weather, and other factors. Ginseng roots are considered most valuable between 4 and 6 years of age. Roots younger than 4 years are considered immature, and should not be used for medical purposes [195].

Panax ginseng radix is included in the European pharmacopoeia [199]. According to the European pharmacopeia, the root should have a cylindrical or fusiform shape with 
a length of $20 \mathrm{~cm}$ and a $2.5 \mathrm{~cm}$ diameter. The root surface should be pale yellow to brownish-red [199].

Nowadays, Panax ginseng extract is associated with antitumor, anti-fatigue, antioxidative, immunostimulating, anti-inflammation, anti-obesity, cardioprotective, antimicrobial and neuroprotective activities. The extract is also used because of its adaptogenic properties, as an antioxidant and as an aphrodisiac [195,198,200-202]. The intake of this extract is not associated with side effects [35,203-206].

The main active ingredients in Panax ginseng are saponins, also known as ginsenosides [201]. They include tetracyclic triterpenoid saponins of the dammarane type (four-ring carbon skeleton) and oleanane type (five-ring carbon skeleton) $[198,201,202,207,208]$. They consist of gonane, with 17 carbon atoms arranged in four rings [209]. Over 30 ginsenosides have been isolated from Panax [210]. It is considered that ginsenosides are responsible for the adaptogenic properties of Panax ginseng [198]. Other well-known effects of ginsenosides are related to anti-inflammatory activity, neuroprotective activity, antidiabetic effects, nootropic activity, and many other factors $[207,211,212]$. The variety of these activities of ginsenosides is based on the quantity and the positions of hydroxyl groups [213]. Ginsenosides can be isolated not only from Panax ginseng, but also from all of Panax species, such as Panax quinquefolius L., Panax notoginseng (Burkill) F. H. Chen, Panax japonicas (T. Nees) C. A. Mey. and Panax zingiberensis C. Y. Wu and K. M. Feng [207,214-216].

According to studies involving humans, ginsenosides may improve calmness, mental health, and the overall quality of life. Moreover, their intake is associated with antihyperlipidemic, antidiabetic, and anti-fatigue effects [203,206,217-220]. The data obtained from animal studies suggest that ginsenosides could be included in the management of diabetes and cardiovascular diseases, in the treatment of impaired immunity, or could be used as hepatoprotectors [203,221-226].

Although Panax ginseng is a source of plenty of biological active compounds, the molecules with the greatest potential to become drug molecules are ginsenosides. According to data obtained from animal studies, ginsenosides have great potential to be used for the treatment of cardiovascular diseases, hepatic disorders and obesity [227-233]. According to data obtained from cell culture studies, ginsenosides have great potential to be used for the treatment cardiovascular diseases, hypercholesterolemia, and some types of cancer [234-237].

Table 5 shows the isolated bioactive compounds from Panax ginseng.

Table 5. Bioactive compounds in Panax ginseng.

\begin{tabular}{ccc}
\hline Biological Active Compound & Plant Part & References \\
\hline \multicolumn{1}{c}{ Saponins and their glycosides } & \\
\hline $\begin{array}{c}\text { Ginsenoside Ra1 (20(S)-protopanaxadiol } \\
\text { 3-O- } \beta \text {-D-glucopyranosyl(1-2)- } \beta \text {-D- } \\
\begin{array}{c}\text { glucopyranoside-20-O- } \beta \text {-D-xylopyranosyl }(1-4)-\alpha- \\
\text { L-arabinosyl(1-6)- } \beta \text {-D-glucopyranoside) }\end{array}\end{array}$ & Roots & {$[238,239]$} \\
\hline Ginsenoside Ra2 & Roots & {$[238,239]$} \\
\hline Ginsenoside Ra3 & Roots & {$[240,241]$} \\
\hline Ginsenoside Rb1 & Roots & {$[239-244]$} \\
\hline Ginsenoside Rb2 & Roots & {$[239-244]$} \\
\hline Ginsenoside Rb3 & Roots & {$[240-242]$} \\
\hline Malonyl-Rb & Roots & {$[241]$} \\
\hline Malonyl-Rb1 & Roots & {$[240,241]$} \\
\hline Ginsenodide Rc & Roots & {$[239-244]$} \\
\hline
\end{tabular}


Table 5. Cont.

\begin{tabular}{|c|c|c|}
\hline Biological Active Compound & Plant Part & References \\
\hline Ginsenoside Rd & $\begin{array}{l}\text { Leaves } \\
\text { Roots }\end{array}$ & $\begin{array}{c}{[245]} \\
{[239-244]}\end{array}$ \\
\hline Malonyl-Rd & Roots & [240] \\
\hline Ginsenoside Re & $\begin{array}{l}\text { Roots } \\
\text { Leaves }\end{array}$ & $\begin{array}{c}{[239-243,246]} \\
{[245]}\end{array}$ \\
\hline Ginsenoside Rf & Roots & [239-243,246,247] \\
\hline 20-Glc-Rf & Roots & [240] \\
\hline Ginsenoside Rg1 & $\begin{array}{l}\text { Roots } \\
\text { Leaves }\end{array}$ & $\begin{array}{c}{[239-243,247]} \\
{[245]}\end{array}$ \\
\hline Ginsenoside Rg2 & Roots & {$[239,241,246,247]$} \\
\hline 20(S)-Ginsenoside-Rg2 & Roots & {$[240,242]$} \\
\hline 20(R)-Ginsenoside-Rg2 & Roots & [242] \\
\hline Ginsenoside Rg3 & Roots & [239] \\
\hline 20(S)-Ginsenoside-Rg3 & Roots & [243] \\
\hline 20(R)-Ginsenoside-Rg3 & Roots & {$[242,243]$} \\
\hline $\mathrm{Rg} 3 /$ isomer & Roots & [240] \\
\hline Ginsenoside Rg5 & Roots & [243] \\
\hline Ginsenoside Rg6 & Roots & [243] \\
\hline $\begin{array}{c}\text { Ginsenoside } \mathrm{Rg} 7 \text { (3-O- } \beta \text {-D-glucopyranosyl } \\
3 \beta, 12 \beta, 20(\mathrm{~S}), 24(\mathrm{R}) \text {-tetrahydroxy-dammar-25-ene } \\
\text { 20-O- } \beta \text {-D-glucopyranoside) }\end{array}$ & Leaves & [248] \\
\hline Ginsenoside Rh & Roots & {$[239,242]$} \\
\hline Ginsenoside 20(S)-Rh1 & Roots & {$[240,242]$} \\
\hline Ginsenoside Rh4 & Roots & {$[240,243]$} \\
\hline $\begin{array}{c}\text { Ginsenoside } \operatorname{Rh} 5(3 \beta, 6 \alpha, 12 \beta, 24 x \text { tetrahydroxy- } \\
\text { dammar-20(22),25-diene } \\
\text { 6-O- } \beta \text {-D-glucopyranoside })\end{array}$ & Leaves & [248] \\
\hline $\begin{array}{c}\text { Ginsnoside Rh6 }(3 \beta, 6 \alpha, 12 \beta, 20(\mathrm{~S}) \text {-tetrahydroxy-25- } \\
\text { hydroperoxy-dammar-23-ene } \\
\text { 20-O- } \beta \text {-D-glucopyranoside })\end{array}$ & Leaves & [248] \\
\hline $\begin{array}{c}\text { Ginsenoside Rh7 } \\
(3 \beta, 7 \beta, 12 \beta, 20(\mathrm{~S}) \text {-tetrahydroxy-dammar-5,24-diene } \\
\text { 20-O- } \beta \text {-D-glucopyranoside })\end{array}$ & Leaves & [248] \\
\hline $\begin{array}{c}\text { Ginsenoside Rh8 } \\
(3 \beta, 6 \alpha, 20(\mathrm{~S}) \text {-trihydroxy-dammar-24-ene-12-one } \\
\text { 20-O- } \beta \text {-D-glucopyranoside })\end{array}$ & Leaves & [248] \\
\hline $\begin{array}{c}\text { Ginsenoside } \mathrm{Rh} 9(3 \beta, 6 \alpha, 20(\mathrm{~S}) \text {-trihydroxy-12b,23- } \\
\text { epoxy-dammar-24-ene } \\
\text { 20-O- } \beta \text {-D-glucopyranoside })\end{array}$ & Leaves & [248] \\
\hline Ginsenoside Rk1 & Roots & {$[243,249]$} \\
\hline Ginsenoside Rk2 & Roots & [249] \\
\hline Ginsenoside Rk3 & Roots & {$[243,249]$} \\
\hline Ginsenoside Ro & Roots & {$[239,241,242,244]$} \\
\hline Ginsenoside Ro isomer & Roots & [240] \\
\hline Polyacetyleneginsenoside-Ro & Roots & [247] \\
\hline
\end{tabular}


Table 5. Cont.

\begin{tabular}{|c|c|c|}
\hline Biological Active Compound & Plant Part & References \\
\hline Ginsenoside-Ro methyl ester & Roots & [247] \\
\hline Ginsenoside Rs1 & Roots & [242] \\
\hline 20(S)-Ginsenoside Rs3 & Roots & [243] \\
\hline 20(R)-Ginsenoside Rs3 & Roots & [243] \\
\hline 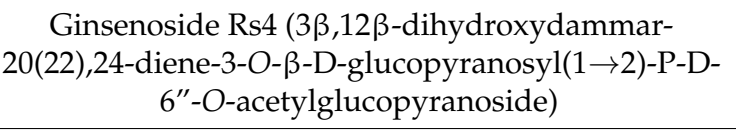 & Roots & {$[243,250]$} \\
\hline $\begin{array}{l}\text { Ginsenoside Rs5 ( } 3 \beta, 12 \beta \text {-dihydroxydammar-20(21), } \\
\text { 24-diene-3-O- } \beta \text {-D-glucopyranosyl }(1 \rightarrow 2)-\beta \text {-D-6"-O- } \\
\text { acetylglucopyranoside })\end{array}$ & Roots & {$[243,250]$} \\
\hline $\begin{array}{c}\text { Ginsenoside Rs6 }(3 \beta \\
6 \alpha, 12 \text { p-trihydro-xydammar-20(22),24-diene-6-O- } \beta \text { - } \\
\text { D-6'-O-acetylglucopyranoside })\end{array}$ & Roots & [250] \\
\hline $\begin{array}{c}\text { Ginsenoside Rs7 }(3 \beta, 6 \alpha, \\
12 \beta \text {-trihydroxydam-mar-20(21),24-diene-6-O- } \beta \text {-D- } \\
\left.6^{\prime} \text {-O-acetylglucopyranoside }\right)\end{array}$ & Roots & [250] \\
\hline $\begin{array}{c}\text { Ginsenoside F1 } \\
\text { (20-O- } \beta \text {-glucopyranosyl-20(S)-protopanaxatriol) }\end{array}$ & Leaves & [245] \\
\hline $\begin{array}{c}\text { Ginsenoside F2 (3, } \\
\text { 20-di-O- } \beta \text {-glucopyranosyl-20(S)-protopanaxadiol) }\end{array}$ & Leaves & [245] \\
\hline $\begin{array}{l}\text { Ginsenoside F3 (20-O- }(\alpha \text {-arabinopyranosyl- }(1 \rightarrow 6)-\beta \text { - } \\
\text { glucopyranosyl)-20(S)-protopanaxatriol) }\end{array}$ & Leaves & [245] \\
\hline Ginsenoside I & Flower buds & [251] \\
\hline Ginsenoside II & Flower buds & [251] \\
\hline Ginsenoside F4 & Roots & [243] \\
\hline Malonyl-Ra1/Ra2 & Roots & [241] \\
\hline Malonyl-Rb2/Rb3/Rc & Roots & [241] \\
\hline Malonyl-Rd Notoginsenoside R2/F3 & Roots & [241] \\
\hline Malonyl-Rd isomer & Roots & [241] \\
\hline $\mathrm{Ra} 1 / \mathrm{Ra} 2 /$ isomer & Roots & {$[240,241]$} \\
\hline Gingerglycolipid B & Roots & [247] \\
\hline Quinginsenoside R1 & Roots & [242] \\
\hline $\begin{array}{c}\text { Koryoginsenoside-R1 (6-O-[trans butenoyl- }(1 \rightarrow 6)-\beta \text { - } \\
\text { D-glucopyranosyl]-20-O- } \beta \text {-D-glucopyranosyl } \\
\text { dammar-24-en-3 } \beta, 6 \alpha, 12 \beta, 20(S) \text {-tetrol })\end{array}$ & Roots & [239] \\
\hline $\begin{array}{l}\text { Koryoginsenoside-R2 3-O-[ } \beta \text {-D-glucopyranosyl- } \\
(1 \rightarrow 2)-\beta \text {-D-glucopyranosyl]-20-O-[ } \beta \text {-D- } \\
\text { glucopyranosyl- }(1 \rightarrow 6)-\beta \text {-D-glucopyranosyl] } \\
\text { dammar-22-en-3 } \beta, 12 \beta, 20(S),-25 \text {-tetrol }\end{array}$ & Roots & [239] \\
\hline Notoginsenoside R1 & Roots & [239] \\
\hline Notoginsenoside R2 & Roots & [240] \\
\hline Notoginseng R2 & Roots & [252] \\
\hline Malonyl-Rg1 & Roots & [240] \\
\hline Malonyl-Rc/Rb2/Rb3 & Roots & [240] \\
\hline $\operatorname{Rg} 6 / F 4$ & Roots & [240] \\
\hline Rg5/Rk1 & Roots & [240] \\
\hline
\end{tabular}




\subsubsection{Phytochemicals Isolated from Panax ginseng Roots}

The main phytochemicals are ginsenosides and their isomers [238-244,246,247,249, 250,252]. Some of the ginsenosides isolated from Panax ginseng include ginsenoside Ra1, ginsenoside $\mathrm{Ra} 2$, ginsenoside $\mathrm{Rb} 1$, ginsenoside $\mathrm{Rb} 2$, ginsenoside $\mathrm{Rb} 3$, ginsenoside $\mathrm{Rc}$, ginsenoside $\mathrm{Rd}$, ginsenoside $\mathrm{Re}$, ginsenoside $\mathrm{Rh}$, ginseoside $\mathrm{Rg} 1$, ginsenoside $\mathrm{Rg} 2$, ginsenoside Rg5, ginsenoside Rf, ginsenoside F2, ginsenoside Rk1, ginsenoside Rs4, and ginsenoside Rs6 [238-244,246,247,249,250]. The average concentration of ginsenoside Ra1 in Panax ginseng roots is $0.03 \%$, and that of ginsenoside Ra2 is $0.02 \%$ [238]. Notoginsenoside R1, notoginsenoside R2, and notoginseng R2 are also detected in Panax ginseng roots $[239,240,245]$.

\subsubsection{Phytochemicals Isolated from Panax ginseng Leaves and Flower Buds}

The main bioactive compounds are the ginsenosides ginsenoside $\mathrm{Rd}$, ginsenoside $\mathrm{Rh} 5$, ginsenoside $\mathrm{Rh} 6$, ginsenoside $\mathrm{Rh} 7$, ginsenoside $\mathrm{Rh} 8$, ginsenoside $\mathrm{Rh} 9$, ginsenoside $\operatorname{Rg} 1$, ginsenoside $\operatorname{Rg} 7$ ginsenoside Re, ginsenoside $\mathrm{F} 1$, ginsenoside $\mathrm{F} 2$, and ginsenoside F3 [245,246]. The ginsenosides isolated from Panax ginseng may be used as melanogenic inhibitors [253]. The phytochemicals detected in flower buds are ginsenoside I and ginsenoside II [251]. The ginsenosides isolated from flower buds may be used for hepatic diseases and tumors [254,255].

\section{Comparison between Rhaponticum carthamoides, Lepidium meyenii, Eleutherococcus senticosus and Panax ginseng and Future Perspectives}

Bioactive compounds and their concentration isolated from plants are not constant. For example, the content of the phytochemicals varies in different parts of the species and also depends on many factors like soil, soil management, climate, and pollutants [55,187,256-258].

For that reason, it is very important the feature research about these plants to be focused mostly on their active molecules that to the whole extracts. However, comparison between the biological activity of the extracts and the active molecules would provide valuable data.

Although the four plants have quite different phytochemical composition (Table 6), the future perspectives for introduction of their specific molecules/ plant extracts as medi-cines are similar $[12,13,22,23]$. Most of them could be included in the management of dia-betes, cardiovascular diseases, or used as nootropic agents and hepatoprotectors (Table 7$)[12,18,35,62,67,132]$. Rhaponticum carthamoides is the only plant among these which has the greatest potential to be used as a remedy for improvement physical performance, because of potential ergogenic activity. Ecdysterone, which is one of its active compounds is in process of monitoring by WADA as a doping compound [65]. Moreover, in near future the extract or its active compounds could be applied for obesity/ overweight management $[259,260]$.

Table 6. Comparison between the main bioactive compounds in Rhaponticum carthamoides, Lepidium meyenii, Eleutherococcus senticosus, and Panax ginseng.

\begin{tabular}{ccccc}
\hline Bioactive Compounds & $\begin{array}{c}\text { Rhaponticum } \\
\text { carthamoides }\end{array}$ & Lepidium meyenii & $\begin{array}{c}\text { Eleutherococcus } \\
\text { senticosus }\end{array}$ & Panax ginseng \\
\hline Phytosteroids & {$[24,47-56,86,87]$} & - & - & - \\
\hline Glucosinolates & - & {$[30,102,114,126,147-150]$} & - & - \\
\hline Alkaloids & - & {$[30,123,147,148,151]$} & - & - \\
\hline Macamides and makaaenes & - & {$[30,97,104,114,115,146-148]$} & {$[28,29,186-188,190-$} \\
\hline Eleutherosides & - & {$[127,152]$} & - & - \\
\hline Ginsenosides & - & - & {$[238-252]$} \\
\hline
\end{tabular}


Table 7. Effects and future perspectives of extracts/ bioactive compounds.

\begin{tabular}{|c|c|c|c|c|}
\hline Effects/Activity & $\begin{array}{l}\text { Rhaponthicum } \\
\text { carthamoides }\end{array}$ & Lepidium meyenii & $\begin{array}{l}\text { Eleutherococcus } \\
\text { senticosus }\end{array}$ & Panax ginseng \\
\hline Weight loss management & + & - & - & - \\
\hline Lipid profile management & + & + & + & + \\
\hline Nootropic activity & + & + & + & + \\
\hline Diabetes management & + & + & + & + \\
\hline Ergogenic activity & $\begin{array}{l}\text { More data are needed. } \\
\text { In process of } \\
\text { monitoring }\end{array}$ & - & - & - \\
\hline Hormones regulation & + & + & - & - \\
\hline Antiviral activity & More data are needed & More data are needed & More data are needed & More data are needed \\
\hline
\end{tabular}

In term to establish the biological activity of Rhaponticum carthamoides, Lepidium meyenii, Eleutherococcus senticosus, Panax ginseng/their active compounds, cell cultures research would be especially useful to give the right direction for future investigations.

\section{Conclusions}

Plants have always played an important role in drug discovery, and their effectiveness is based on hundreds of years' experience in the folk medicines of different nations. In the 1960s, the first plants with adaptogenic activities were described: Rhaponticum carthamoides, Eleutherococcus senticosus, and Panax ginseng. Later, Lepidium meyenii was also included in the plant adaptogens family.

The main phytochemicals isolated from these plants are phytosteroids, phytosterols, alkaloids, and saponins. These biologically active compounds determine the therapeutic effects of plants not only as adaptogens, but also as antioxidants, hepatoprotectors, immunomodulators, hormone regulators, and others. Plants have always been an important source of past and novel drug molecules. In our view, there is great potential for some of the phytochemicals found in these plant species, such as ginsenosides, ecdysterone, macamides, macaenes, and eleutherosides to become novel drug molecules. However, their biological activity should be studied in more detail in cell cultures, in mammals, and in randomized clinical trials.

Author Contributions: Conceptualization, V.T., K.I., and S.I.; data curation, V.T., K.I., and S.I.; writing-original draft preparation, V.T., K.I., and S.I.; writing—review and editing, V.T., K.I., and S.I.; visualization, V.T., K.I., and S.I.; supervision, V.T., K.I., and S.I. All authors have read and agreed to the published version of the manuscript.

Funding: This research received no external funding.

Institutional Review Board Statement: Not applicable.

Informed Consent Statement: Not applicable.

Data Availability Statement: Not applicable.

Conflicts of Interest: The authors declare no conflict of interest.

\section{References}

1. Wagner, H.; Nörr, H.; Winterhoff, H. Plant Adaptogens. Phytomedicine 1994, 1, 63-76. [CrossRef]

2. Panossian, A.; Wikman, G.; Wagner, H. Plant Adaptogens III. Earlier and More Recent Aspects and Concepts on Their Mode of Action. Phytomedicine 1999, 6, 287-300. [CrossRef]

3. Panossian, A.G.; Efferth, T.; Shikov, A.N.; Pozharitskaya, O.N.; Kuchta, K.; Mukherjee, P.K.; Banerjee, S.; Heinrich, M.; Wu, W.; Guo, D.A.; et al. Evolution of the Adaptogenic Concept from Traditional Use to Medical Systems: Pharmacology of Stress- and Aging-Related Diseases. Med. Res. Rev. 2021, 41, 630-703. [CrossRef] 
4. Brekhman, I.I.; Dardymov, I.V. New Substances of Plant Origin Which Increase Nonspecific Resistance. Annu. Rev. Pharmacol. 1969, 9, 419-430. [CrossRef] [PubMed]

5. Panossian, A.G. Adaptogens: Tonic Herbs for Fatigue and Stress. Altern. Complement. Ther. 2003, 9, 327-331. [CrossRef]

6. Rai, D.; Bhatia, G.; Palit, G.; Pal, R.; Singh, S.; Singh, H.K. Adaptogenic Effect of Bacopa Monniera (Brahmi). Pharmacol. Biochem. Behav. 2003, 75, 823-830. [CrossRef]

7. Shivakumar, H.; Javed, T.; Prakash, T.; Rao, R.N.; Swamy, B.H.M.J.; Goud, A.V. Adaptogenic Activity of Ethanolic Extract of Tribulus terrestris L. J. Nat. Remedies 2006, 6, 87-95. [CrossRef]

8. Ley, B.M. Maca!: Adaptogen and Hormonal Regulator; BL Publications: Memphis, TN, USA, 2003; ISBN 9781890766252.

9. Gupta, G.; Rana, A.C. Withania Somnifera (Ashwagandha): A Review. Pharmacogn. Rev. 2007, 1, 129-136.

10. Iwu, M.M.; Diop, A.D.; Meserole, L.; Okunji, C.O. Chapter 17-Garcinia Kola: A New Look at an Old Adaptogenic Agent. In Advances in Phytomedicine: Ethnomedicine and Drug Discovery; Iwu, M.M., Wootton, J.C., Eds.; Elsevier: Amsterdam, The Netherlands, 2002; Volume 1, pp. 191-199.

11. Kamal, M.; Arif, M.; Jawaid, T. Adaptogenic Medicinal Plants Utilized for Strengthening the Power of Resistance during Chemotherapy-A Review. Orient. Pharm. Exp. Med. 2017, 17, 1-18. [CrossRef]

12. Davydov, M.; Krikorian, A.D. Eleutherococcus senticosus (Rupr. \& Maxim.) Maxim. (Araliaceae) as an Adaptogen: A Closer Look. J. Ethnopharmacol. 2000, 72, 345-393. [CrossRef]

13. Kokoska, L.; Janovska, D. Chemistry and Pharmacology of Rhaponticum carthamoides: A Review. Phytochemistry 2009, $70,842-855$ [CrossRef]

14. Gan, J.; Feng, Y.; He, Z.; Li, X.; Zhang, H. Correlations between Antioxidant Activity and Alkaloids and Phenols of Maca (Lepidium meyenii). J. Food Qual. 2017, 2017, e3185945. [CrossRef]

15. Shergis, J.L.; Zhang, A.L.; Zhou, W.; Xue, C.C. Panax ginseng in Randomised Controlled Trials: A Systematic Review. Phytother Res. 2013, 27, 949-965. [CrossRef]

16. Coleman, C.I.; Hebert, J.H.; Reddy, P. The Effects of Panax ginseng on Quality of Life. J. Clin. Pharm. Ther. 2003, 28, 5-15. [CrossRef] [PubMed]

17. Biskup, E.; Lojkowska, E. Evaluation of Biological Activities of Rhaponticum carthamoides Extracts. JMPR 2009, 3, 1092-1098. [CrossRef]

18. Peres, N.D.S.L.; Bortoluzzi, L.C.P.; Marques, L.L.M.; Formigoni, M.; Barros Fuchs, R.H.; Aparecida Droval, A.; Cardoso, F.A.R. Medicinal Effects of Peruvian Maca (Lepidium meyenii): A Review. Food Funct. 2020, 11, 83-92. [CrossRef] [PubMed]

19. Panossian, A.; Rebecca, H.; Kadioglu, O.; Georg, W.; Efferth, T. Understanding Adaptogens: New Evidence on Their Possible Effectiveness in Stress-Induced and Ageing-Associated Disorders from a DNA Microarray Study of Neuroglia Cells. Planta Med. 2013, 79, PM8. [CrossRef]

20. Pawar, V.S.; Shivakumar, H. A Current Status of Adaptogens: Natural Remedy to Stress. Asian Pac. J. Trop. Dis. 2012, 2, S480-S490. [CrossRef]

21. Page, M.J.; McKenzie, J.E.; Bossuyt, P.M.; Boutron, I.; Hoffmann, T.C.; Mulrow, C.D.; Shamseer, L.; Tetzlaff, J.M.; Akl, E.A.; Brennan, S.E.; et al. The PRISMA 2020 Statement: An Updated Guideline for Reporting Systematic Reviews. BMJ 2021, 372 , n71. [CrossRef]

22. Dini, A.; Migliuolo, G.; Rastrelli, L.; Saturnino, P.; Schettino, O. Chemical Composition of Lepidium meyenii. Food Chem. 1994, 49, 347-349. [CrossRef]

23. Lee, S.M.; Bae, B.S.; Park, H.W.; Ahn, N.G.; Cho, B.G.; Cho, Y.L.; Kwak, Y.S. Characterization of Korean Red Ginseng (Panax ginseng Meyer): History, Preparation Method, and Chemical Composition. J. Ginseng Res. 2015, 39, 384-391. [CrossRef] [PubMed]

24. Koleckar, V.; Brojerova, E.; Rehakova, Z.; Kubikova, K.; Cervenka, F.; Kuca, K.; Jun, D.; Hronek, M.; Opletalova, V.; Opletal, L. In Vitro Antiplatelet Activity of Flavonoids from Leuzea carthamoides. Drug Chem. Toxicol. 2008, 31, 27-35. [CrossRef] [PubMed]

25. Koleckar, V.; Opletal, L.; Macakova, K.; Jahodar, L.; Jun, D.; Kunes, J.; Kuca, K. New Antioxidant Flavonoid Isolated from Leuzea carthamoides. J. Enzyme Inhib. Med. Chem. 2010, 25, 143-145. [CrossRef] [PubMed]

26. Sharaf, M.; Skiba, A.; Weglarz, Z.; El-Ansari, M.A. Two Flavonol 5-O-Glycosides from the Roots of Leuzea carthamoides. Fitoterapia 2001, 72, 940-942. [CrossRef]

27. Skiba, A.; Weglarz, Z. Phenolic Acids of Rhaponticum carthamoides. Acta Hortic. 2003, 119-124. [CrossRef]

28. Wagner, H.; Heur, Y.H.; Obermeier, A.; Tittel, G.; Bladt, S. Die DC-and HPLC-analyse der Eleutherococcus Droge. Planta Med. 1982, 44, 193-198. [CrossRef]

29. Kurkin, V.A.; Zapesochnaya, G.G.; Bandyshev, V.V. Phenolic Compounds of Eleutherococcus senticosus. Chem. Nat. Compd. 1991, 27, 755-756. [CrossRef]

30. Li, J.; Chen, L.; Li, J.; Duan, Z.; Zhu, S.; Fan, L. The Composition Analysis of Maca (Lepidium meyenii Walp.) from Xinjiang and Its Antifatigue Activity. J. Food Qual. 2017, 2017, e2904951. [CrossRef]

31. Timofeev, N.P. Leuzea carthamoides DC.: Application Prospects as Pharmpreparations and Biologically Active Components. In Functional Foods for Chronic Diseases: The Modern Day Cure without the Side Effects of Traditional Treatments; Martirosyan, D.M., Ed.; D \& A Inc.: Richardson, TX, USA, 2006; pp. 105-120. ISBN 9780976753520.

32. Petkov, V.; Roussinov, K.; Todorov, S.; Lazarova, M.; Yonkov, D.; Draganova, S. Pharmacological Investigations on Rhaponticum carthamoides. Planta Med. 1984, 50, 205-209. [CrossRef] 
33. Ewa, S.; Picot, L.; Saluk-Bijak, J.; Szemraj, J.; Kicel, A.; Olszewska, M.; Sitarek, P.; Bijak, M. An Efficient Plant Regeneration from Rhaponticum carthamoides Transformed Roots, Enhanced Caffeoylquinic Acid Derivatives Production in PRi-Transformed Plants and Their Biological Activity. Ind. Crop. Prod. 2019, 129, 327-338. [CrossRef]

34. State Pharmacopoeia of the Russian Federation/Ministry of Health of the Russian Federation, 14th ed.; The Ministry of Health of the Russian Federation: Moscow, Russia, 2018; Volume 4, pp. 6360-6368.

35. Todorova, V.; Ivanov, K.; Delattre, C.; Nalbantova, V.; Karcheva-Bahchevanska, D.; Ivanova, S. Plant Adaptogens-History and Future Perspectives. Nutrients 2021, 13, 2861. [CrossRef]

36. Isenmann, E.; Ambrosio, G.; Joseph, J.F.; Mazzarino, M.; de la Torre, X.; Zimmer, P.; Kazlauskas, R.; Goebel, C.; Botrè, F.; Diel, P.; et al. Ecdysteroids as Non-Conventional Anabolic Agent: Performance Enhancement by Ecdysterone Supplementation in Humans. Arch. Toxicol. 2019, 93, 1807-1816. [CrossRef]

37. Wilborn, C.D.; Taylor, L.W.; Campbell, B.I.; Kerksick, C.; Rasmussen, C.J.; Greenwood, M.; Kreider, R.B. Effects of Methoxyisoflavone, Ecdysterone, and Sulfo-Polysaccharide Supplementation on Training Adaptations in Resistance-Trained Males. J. Int. Soc. Sports Nutr. 2006, 3, 19-27. [CrossRef]

38. Ryan, E.D.; Gerstner, G.R.; Mota, J.A.; Trexler, E.T.; Giuliani, H.K.; Blue, M.N.M.; Hirsch, K.R.; Smith-Ryan, A.E. The Acute Effects of a Multi-Ingredient Herbal Supplement on Performance Fatigability: A Double-Blind, Randomized, and Placebo-Controlled Trial. J. Diet. Suppl. 2021, 18, 507-516. [CrossRef]

39. Głazowska, J.; Kamiński, M.M.; Kamiński, M. Chromatographic Separation, Determination and Identification of Ecdysteroids: Focus on Maral Root (Rhaponticum carthamoides, Leuzea carthamoides). J. Sep. Sci. 2018, 41, 4304-4314. [CrossRef]

40. Skała, E.; Rijo, P.; Garcia, C.; Sitarek, P.; Kalemba, D.; Toma, M.; Szemraj, J.; Pytel, D.; Wysokińska, H.; Śliwiński, T. The Essential Oils of Rhaponticum carthamoides Hairy Roots and Roots of Soil-Grown Plants: Chemical Composition and Antimicrobial, Anti-Inflammatory, and Antioxidant Activities. Oxid. Med. Cell. Longev. 2016, 2016, 8505384. [CrossRef]

41. Dinan, L. Phytoecdysteroids: Biological Aspects. Phytochemistry 2001, 57, 325-339. [CrossRef]

42. Das, N.; Mishra, S.K.; Bishayee, A.; Ali, E.S.; Bishayee, A. The Phytochemical, Biological, and Medicinal Attributes of Phytoecdysteroids: An Updated Review. Acta Pharm. Sin. B 2021, 11, 1740-1766. [CrossRef] [PubMed]

43. Bathori, M.; Toth, N.; Hunyadi, A.; Marki, A.; Zador, E. Phytoecdysteroids and Anabolic-Androgenic Steroids-Structure and Effects on Humans. CMC 2008, 15, 75-91. [CrossRef] [PubMed]

44. Tarkowská, D.; Strnad, M. Plant Ecdysteroids: Plant Sterols with Intriguing Distributions, Biological Effects and Relations to Plant Hormones. Planta 2016, 244, 545-555. [CrossRef] [PubMed]

45. Szendrei, K.; Varga, E.; Hajdú, Z.; Herke, I.; Lafont, R.; Girault, J.P. Ajugasterone C and 5-Deoxykaladasterone, an Ecdysteroid Artifact, from Leuzea carthamoides. J. Nat. Prod. 1988, 51, 993-995. [CrossRef]

46. Bathori, M.; Pongracz, Z. Phytoecdysteroids-From Isolation to Their Effects on Humans. Curr. Med. Chem. 2005, 12, 153-172. [CrossRef] [PubMed]

47. Timofeev, N.P.; Chukhchin, D.G. Accumulation and Composition of Extractive Substances from Above-Ground and Underground Bodies of Levzei safloroid. In Proceedings of the New Achievements in Chemistry and Chemical Technology of Vegetable Raw Materials: Materials of the IV All-Russian Conference. April 21-23, 2009; Bazarnova, N.G., Markin, V.I., Eds.; Altajskogo Gos. Univ.: Burnau, Russia, 2009; pp. 145-147. ISBN 978-5-7904-0903-5.

48. Píš, J.; Buděšínsky, M.; Vokáč, K.; Laudová, V.; Harmatha, J. Ecdysteroids from the Roots of Leuzea carthamoides. Phytochemistry 1994, 37, 707-711. [CrossRef]

49. Vokáč, K.; Budesinsky, M.; Harmatha, J. Minor Ecdysteroid Components of Leuzea carthamoides. Collect. Czechoslov. Chem. Commun. 2002, 67, 124-139. [CrossRef]

50. Buděšínský, M.; Vokáč, K.; Harmatha, J.; Cvačka, J. Additional Minor Ecdysteroid Components of Leuzea carthamoides. Steroids 2008, 73, 502-514. [CrossRef]

51. Girault, J.P.; Lafont, R.; Varga, E.; Hajdu, Z.; Herke, I.; Szendrei, K. Ecdysteroids from Leuzea carthamoides. Phytochemistry 1988, 27, 737-741. [CrossRef]

52. Mamatkhanov, A.U.; Shamsutdinov, M.-R.I.; Shakirov, T.T. Isolation of Ecdysterone from the Roots of Rhaponticum carthamoides. Chem. Nat. Compd. 1980, 16, 381-382. [CrossRef]

53. Timofeev, N.P.; Volodin, V.V.; Frolov, Y.M. Distribution of 20-hydroxyecdysone in the structure of the biomass of the aboveground part of Rhaponticum carthamoides (Willd.) Iljin. 7. Russ. Acad. Sci. 1998, 34, 63-69.

54. Ramazanov, N.S.; Makshimov, E.S.; Saatov, Z.; Mamatkhanov, A.U.; Abdullaev, N.D. Phytoecdysteroids of Plants of the Genus Rhaponticum I. Carthamosterone a FromRh. Carthamoides. Chem. Nat. Compd. 1997, 33, 301-302. [CrossRef]

55. Sovová, H.; Opletal, L.; Sajfrtová, M.; Bártlová, M. Supercritical Fluid Extraction of Cynaropicrin and 20-Hydroxyecdysone from Leuzea carthamoides DC. J. Sep. Sci. 2008, 31, 1387-1392. [CrossRef] [PubMed]

56. Sadykov, Z.T.; Ramazanov, N.S.; Saatov, Z. Phytoecdysteroids of Plants of the GenusRhaponticum Polypodin B 22-O-Benzoate from Rhaponticum carthamoides. Chem. Nat. Compd. 1997, 33, 665-666. [CrossRef]

57. Ferro, N.; Tacoronte, J.E.; Reinard, T.; Bultinck, P.; Montero, L.A. Structure-Activity Analysis on Ecdysteroids: A Structural and Quantum Chemical Approach Based on Two Biological Systems. J. Mol. Struct. Theochem. 2006, 758, 263-274. [CrossRef]

58. Dinan, L. Ecdysteroid Structure-Activity Relationships. In Studies in Natural Products Chemistry: Bioactive Natural Products (Part J); Attaur-Rahman, Ed.; Elsevier: Amsterdam, The Netherlands, 2003; Volume 29, pp. 3-71. 
59. Syrov, V.N.; Saatov, Z.; Sagdullaev, S.S.; Mamatkhanov, A.U. Study of the Structure-Anabolic Activity Relationship for Phytoecdysteroids Extracted from Some Plants of Central Asia. Pharm. Chem. J. 2001, 35, 667-671. [CrossRef]

60. Cahlíková, L.; Macáková, K.; Chlebek, J.; Hošt'álková, A.; Kulhánková, A.; Opletal, L. Ecdysterone and Its Activity on Some Degenerative Diseases. Nat. Prod. Commun. 2011, 6, 1934578X1100600527. [CrossRef]

61. Lafont, R.; Dinan, L. Practical Uses for Ecdysteroids in Mammals Including Humans: And Update. J. Insect Sci. 2003, 3. [CrossRef]

62. Dinan, L.; Dioh, W.; Veillet, S.; Lafont, R. 20-Hydroxyecdysone, from Plant Extracts to Clinical Use: Therapeutic Potential for the Treatment of Neuromuscular, Cardio-Metabolic and Respiratory Diseases. Biomedicines 2021, 9, 492. [CrossRef]

63. Bakrim, A.; Maria, A.; Sayah, F.; Lafont, R.; Takvorian, N. Ecdysteroids in Spinach (Spinacia oleracea L.): Biosynthesis, Transport and Regulation of Levels. Plant Physiol. Biochem. 2008, 46, 844-854. [CrossRef]

64. Imai, S.; Toyosato, T.; Sakai, M.; Sato, Y.; Fujioka, S.; Murata, E.; Goto, M. Isolation of Cyasterone and Ecdysterone from Plant Materials. Chem. Pharm. Bull. 1969, 17, 340-342. [CrossRef]

65. The World Anti-Doping Agency-WADA. The 2020 Monitoring Program. Available online: https://www.wada-ama.org/sites/ default/files/resources/files/wada_2020_english_monitoring_program_pdf (accessed on 30 November 2021).

66. Tóth, N.; Szabó, A.; Kacsala, P.; Héger, J.; Zádor, E. 20-Hydroxyecdysone Increases Fiber Size in a Muscle-Specific Fashion in Rat. Phytomedicine 2008, 15, 691-698. [CrossRef] [PubMed]

67. Syrov, V.N. Comparative Experimental Investigation of the Anabolic Activity of Phytoecdysteroids and Steranabols. Pharm. Chem. J. 2000, 34, 193-197. [CrossRef]

68. Seidlova-Wuttke, D.; Ehrhardt, C.; Wuttke, W. Metabolic Effects of 20-OH-ecdysone in Ovariectomized Rats. J. Steroid Biochem. Mol. Biol. 2010, 119, 121-126. [CrossRef]

69. Buniam, J.; Chukijrungroat, N.; Rattanavichit, Y.; Surapongchai, J.; Weerachayaphorn, J.; Bupha-Intr, T.; Saengsirisuwan, V. 20-Hydroxyecdysone Ameliorates Metabolic and Cardiovascular Dysfunction in High-fat-high-fructose-fed Ovariectomized Rats. BMC Complement. Med. Ther. 2020, 20, 140. [CrossRef]

70. Zhang, X.; Xu, X.; Xu, T.; Qin, S. $\beta$-Ecdysterone Suppresses Interleukin-1 $\beta$-Induced Apoptosis and Inflammation in Rat Chondrocytes via Inhibition of NF-KB Signaling Pathway. Drug Dev. Res. 2014, 75, 195-201. [CrossRef] [PubMed]

71. Krasutsky, A.G.; Cheremisinov, V.N. The use of Levzey's extract to increase the efficiency of the training process in fitness clubs students. In Proceedings of the Actual Problems of Biochemistry and Bioenergy of Sport of the XXI Century, Moscow, Russia, 10-26 April 2017; pp. 382-388.

72. Vanyuk, A.I. Evaluation of the Effectivnness of Rehabilitation Measures Among Female Volleyball Players 18-22 Years Old in the Competitive Period of the Annual Training Cycle. Slobozhanskiy Sci. Sports Visnik. 2012, 5, 95-98.

73. Timofeev, N.P.; Koksharov, A.V. Study of Leuzea from Leaves: Results of 15 Years of Trials in Athletics. New Unconv. Plants Prospect. Use 2016, 12, 502-505.

74. Krasutsky, A.G.; Cheremisinov, V.N. Research of the Influence of Adaptogens on Increasing the Efficacy of the Training Process in Fitness Clubs. In Proceedings of the Current Problems of Biochemistry and Bioenergy Sport of the XXI Century, Moscow, Russia, 10-12 April 2018; pp. 267-282.

75. Chen, Q.; Xia, Y.; Qiu, Z. Effect of Ecdysterone on Glucose Metabolism in Vitro. Life Sci. 2006, 78, 1108-1113. [CrossRef]

76. Romaniuk-Drapała, A.; Lisiak, N.; Totoń, E.; Matysiak, A.; Nawrot, J.; Nowak, G.; Kaczmarek, M.; Rybczyńska, M.; Rubiś, B. Proapoptotic and Proautophagic Activity of 20-Hydroxyecdysone in Breast Cancer Cells in Vitro. Chem. Biol. Interact. 2021, 342. [CrossRef]

77. Shuvalov, O.; Fedorova, O.; Tananykina, E.; Gnennaya, Y.; Daks, A.; Petukhov, A.; Barlev, N.A. An Arthropod Hormone, Ecdysterone, Inhibits the Growth of Breast Cancer Cells via Different Mechanisms. Front. Pharmacol. 2020, 11, 561537. [CrossRef] [PubMed]

78. Xu, T.; Niu, C.; Zhang, X.; Dong, M. $\beta$-Ecdysterone Protects SH-SY5Y Cells against $\beta$-Amyloid-Induced Apoptosis via c-Jun N-Terminal Kinase- and Akt-Associated Complementary Pathways. Lab. Investig. 2018, 98, 489-499. [CrossRef] [PubMed]

79. Tang, Y.H.; Yue, Z.S.; Li, G.S.; Zeng, L.R.; Xin, D.W.; Hu, Z.Q.; Xu, C.D. Effect of B-ecdysterone on Glucocorticoid-induced Apoptosis and Autophagy in Osteoblasts. Mol. Med. Rep. 2018, 17, 158-164. [CrossRef]

80. Panche, A.N.; Diwan, A.D.; Chandra, S.R. Flavonoids: An Overview. J. Nutr. Sci. 2016, 5, e47. [CrossRef] [PubMed]

81. Pietta, P.G. Flavonoids as Antioxidants. J. Nat. Prod. 2000, 63, 1035-1042. [CrossRef] [PubMed]

82. Faizieva, S.K.; Khushbaktova, Z.A.; Syrov, V.N.; Yuldashev, M.P.; Batirov, É.K.; Sagdullaev, S.S. The Total Flavonoids from Thermopsis Alterniflora, Th. Dolichocarpa, Vexibia Alopecuroides, and Rhaponticum carthamoides and Their Hypolipidemic Activity. Chem. Nat. Compd. 1999, 35, 155-158. [CrossRef]

83. Glevitzky, I.; Dumitrel, G.A.; Glevitzky, M.; Pasca, B.; Otrisal, P.; Bungau, S.; Cioca, G.; Pantis, C.; Popa, M. Statistical Analysis of the Relationship Between Antioxidant Activity and the Structure of Flavonoid Compounds. Rev. Chim. 2019, 70, $3103-3107$. [CrossRef]

84. Havlik, J.; Budesinsky, M.; Kloucek, P.; Kokoska, L.; Valterova, I.; Vasickova, S.; Zeleny, V. Norsesquiterpene Hydrocarbon, Chemical Composition and Antimicrobial Activity of Rhaponticum carthamoides Root Essential Oil. Phytochemistry 2009, 70, 414-418. [CrossRef]

85. Geszprych, A.; Weglarz, Z. Composition of Essential Oil from Underground and Aboveground Organs of Rhaponticum carthamoides [Willd.] Iljin. Herba Pol. 2002, 4, 188-192.

86. Bastaev, U.A.; Abubakirov, N.K. Phytoecdysteroids of Rhaponticum carthamoides. Chem. Nat. Compd. 1987, 23, 565-568. [CrossRef] 
87. Timofeev, N.P. Variability of Contnet Ecdysterone in Leaves Rhaponticum carthamoides During Season of Vegetation. In Renewable Wood and Plant Resources: Chemistry, Technology, Pharmacology, Medicine; Saint-Petersburg State Forest Technical Academy: St. Petersburg, Russia, 2011; pp. 228-229.

88. Timofeev, N.P.; Lapin, A.A.; Zelenkov, V.N. Quality Assessment of Rhaponticum carthamoides (Willd.) Iljin as Medicinal Raw Material by the Bromic Antioxidant Capacity Estimation. In Functional Foods for Chronic Diseases; D \& A Inc.: St. Anthony, ID, USA, 2006; pp. 164-172.

89. Krasnov, E.A.; Saratikov, A.S.; Yakunina, G.D. Inokosterone and Ecdysterone from Rhaponticum carthamoides. Chem. Nat. Compd. 1976, 12, 494-495. [CrossRef]

90. Borovikova, E.B.; Shangaraeva, G.S.; Baltaev, U.A. Rhapisterone D 20-Acetate from the Seeds of Leuzea carthamoides. Chem. Nat. Compd. 1999, 35, 184-185. [CrossRef]

91. Baltaev, U.A. Phytoecdysteroids of Rhaponticum carthamoides. II. Rhapisterone B. Chem. Nat. Compd. 1991, 27, 712-713. [CrossRef]

92. Baltaev, U.A. Phytoecdysteroids of Rhaponticum carthamoides III. Rhapisterone C. Chem. Nat. Compd. 1992, 28, 198-200. [CrossRef]

93. Baltaev, U.A. Rapisterone D, a Phytoecdysteroid from Rhaponticum carthamoides. Phytochemistry 1995, 38, 799-800. [CrossRef]

94. Huang, M.F.; Li, N.; Ni, H.; Jia, X.G.; Li, X. Studies on Chemical Constituents from Rhaponticum carthamoides (Willd.) Iljin. Chin. Pharm. J. 2009, 17, 1287-1290.

95. Wang, Y.; Wang, Y.; McNeil, B.; Harvey, L.M. Maca: An Andean Crop with Multi-Pharmacological Functions. Food Res. Int. 2007, 40, 783-792. [CrossRef]

96. Kasprzak, D.; Jodlowska-Jedrych, B.; Borowska, K.; Wojtowicz, A. Lepidium meyenii (Maca)—Multidirectional Health Effects— Review. Curr. Issues Pharm. Med. Sci. 2018, 31, 107-112. [CrossRef]

97. Muhammad, I.; Zhao, J.; Dunbar, D.C.; Khan, I.A. Constituents of Lepidium meyenii 'Maca'. Phytochemistry 2002, 59, 105-110. [CrossRef]

98. León, J. The "Maca” (Lepidium meyenii), a Little Known Food Plant of Peru. Econ. Bot. 1964, 18, 122-127. [CrossRef]

99. Gonzales, C.; Rubio, J.; Gasco, M.; Nieto, J.; Yucra, S.; Gonzales, G.F. Effect of Short-Term and Long-Term Treatments with Three Ecotypes of Lepidium meyenii (MACA) on Spermatogenesis in Rats. J. Ethnopharmacol. 2006, 103, 448-454. [CrossRef] [PubMed]

100. Ganzera, M.; Zhao, J.; Muhammad, I.; Khan, I.A. Chemical Profiling and Standardization of Lepidium meyenii (Maca) by Reversed Phase High Performance Liquid Chromatography. Chem. Pharm. Bull. 2002, 50, 988-991. [CrossRef]

101. Cicero, A.F.G.; Bandieri, E.; Arletti, R. Lepidium meyenii Walp. Improves Sexual Behaviour in Male Rats Independently from Its Action on Spontaneous Locomotor Activity. J. Ethnopharmacol. 2001, 75, 225-229. [CrossRef]

102. Piacente, S.; Carbone, V.; Plaza, A.; Zampelli, A.; Pizza, C. Investigation of the Tuber Constituents of Maca (Lepidium meyenii Walp.). J. Agric. Food Chem. 2002, 50, 5621-5625. [CrossRef]

103. Zhao, J.; Muhammad, I.; Dunbar, D.C.; Mustafa, J.; Khan, I.A. New Alkamides from Maca (Lepidium meyenii). J. Agric. Food Chem. 2005, 53, 690-693. [CrossRef]

104. Melnikovova, I.; Havlik, J.; Cusimamani, E.F.; Milella, L. Macamides and fatty acids content comparison in maca cultivated plant under field conditions and greenhouse. Bol. Latinoam. Caribe Plantas Med. Aromat. 2012, 11, 420-427.

105. Shalaby, E.; Azzam, G.M. Antioxidants in Foods and Its Applications; BoD—Books on Demand: Norderstedt, Germany, 2018; ISBN 9781789233780.

106. Del Valle Mendoza, J.; Pumarola, T.; Gonzales, L.A.; del Valle, L.J. Antiviral Activity of Maca (Lepidium meyenii) against Human Influenza Virus. Asian Pac. J. Trop. Med. 2014, 7, S415-S420. [CrossRef]

107. Chung, F.; Rubio, J.; Gonzales, C.; Gasco, M.; Gonzales, G.F. Dose-Response Effects of Lepidium meyenii (Maca) Aqueous Extract on Testicular Function and Weight of Different Organs in Adult Rats. J. Ethnopharmacol. 2005, 98, 143-147. [CrossRef]

108. Lee, Y.; Jung, S.K.; Chang, Y.H. Rheological Properties of a Neutral Polysaccharide Extracted from Maca (Lepidium meyenii Walp.) Roots with Prebiotic and Anti-Inflammatory Activities. Int. J. Biol. Macromol. 2020, 152, 757-765. [CrossRef] [PubMed]

109. Lentz, A.; Gravitt, K.; Carson, C.C.; Marson, L. Acute and Chronic Dosing of Lepidium meyenii (Maca) on Male Rat Sexual Behavior. J. Sex. Med. 2007, 4, 332-340. [CrossRef] [PubMed]

110. Gonzales, G.F. Ethnobiology and Ethnopharmacology of Lepidium meyenii (Maca), a Plant from the Peruvian Highlands. Evid.Based Complement. Altern. Med. 2011, 2012, e193496. [CrossRef]

111. Wang, S.; Zhu, F. Chemical Composition and Health Effects of Maca (Lepidium meyenii). Food Chem. 2019, 288, 422-443. [CrossRef]

112. Ronald, J.; Davis, S.J. Measuring Hypocotyl Length in Emphasis Type Arabidopsis. Plant Circadian Netw. 2022, 99-106. [CrossRef]

113. Chen, R.; Wei, J.; Gao, Y. A Review of the Study of Active Components and Their Pharmacology Value in Lepidium meyenii (Maca). Phytother. Res. 2021. [CrossRef] [PubMed]

114. Esparza, E.; Hadzich, A.; Kofer, W.; Mithöfer, A.; Cosio, E.G. Bioactive Maca (Lepidium meyenii) Alkamides Are a Result of Traditional Andean Postharvest Drying Practices. Phytochemistry 2015, 116, 138-148. [CrossRef] [PubMed]

115. McCollom, M.M.; Villinski, J.R.; McPhail, K.L.; Craker, L.E.; Gafner, S. Analysis of Macamides in Samples of Maca (Lepidium meyenii) by HPLC-UV-MS/MS. Phytochem. Anal. 2005, 16, 463-469. [CrossRef] [PubMed]

116. Chen, S.X.; Li, K.K.; Pubu, D.; Jiang, S.P.; Chen, B.; Chen, L.R.; Yang, Z.; Ma, C.; Gong, X.J. Optimization of Ultrasound-Assisted Extraction, HPLC and UHPLC-ESI-Q-TOF-MS/MS Analysis of Main Macamides and Macaenes from Maca (Cultivars of Lepidium meyenii Walp). Molecules 2017, 22, 2196. [CrossRef] [PubMed]

117. Fu, L.; Wei, J.; Gao, Y.; Chen, R. Antioxidant and Antitumoral Activities of Isolated Macamide and Macaene Fractions from Lepidium meyenii (Maca). Talanta 2021, 221, 121635. [CrossRef] 
118. Ostlund, R.E. Phytosterols in Human Nutrition. Annu. Rev. Nutr. 2002, 22, 533-549. [CrossRef]

119. Lagarda, M.J.; García-Llatas, G.; Farré, R. Analysis of Phytosterols in Foods. J. Pharm. Biomed. Anal. 2006, 41, 1486-1496. [CrossRef]

120. Li, Y.; Xu, F.; Zheng, M.; Xi, X.; Cui, X.; Han, C. Maca Polysaccharides: A Review of Compositions, Isolation, Therapeutics and Prospects. Int. J. Biol. Macromol. 2018, 111, 894-902. [CrossRef]

121. Sinha, V.R.; Kumria, R. Polysaccharides in Colon-Specific Drug Delivery. Int. J. Pharm. 2001, 224, 19-38. [CrossRef]

122. Nosál'ová, G.; Prisenžňáková, L.; Paulovičová, E.; Capek, P.; Matulová, M.; Navarini, L.; Liverani, F.S. Antitussive and immunomodulating activities of instant coffee arabinogalactan-protein. Int. J. Biol. Macromol. 2011, 49, 493-497. [CrossRef]

123. Zhou, M.; Zhang, R.-Q.; Chen, Y.-J.; Liao, L.-M.; Sun, Y.-Q.; Ma, Z.-H.; Yang, Q.-F.; Li, P.; Ye, Y.-Q.; Hu, Q.-F. Three New Pyrrole Alkaloids from the Roots of Lepidium meyenii. Phytochem. Lett. 2018, 23, 137-140. [CrossRef]

124. Kostova, I.; Bhatia, S.; Grigorov, P.; Balkansky, S.; Parmar, V.S.; Prasad, A.K.; Saso, L. Coumarins as Antioxidants. Curr. Med. Chem. 2011, 18, 3929-3951. [CrossRef]

125. Borges, F.; Roleira, F.; Milhazes, N.; Santana, L.; Uriarte, E. Simple Coumarins and Analogues in Medicinal Chemistry: Occurrence, Synthesis and Biological Activity. Curr. Med. Chem. 2005, 12, 887-916. [CrossRef]

126. Yábar, E.; Pedreschi, R.; Chirinos, R.; Campos, D. Glucosinolate Content and Myrosinase Activity Evolution in Three Maca (Lepidium meyenii Walp.) Ecotypes during Preharvest, Harvest and Postharvest Drying. Food Chem. 2011, 127, 1576-1583. [CrossRef]

127. Zhang, M.; Wang, G.; Lai, F.; Wu, H. Structural Characterization and Immunomodulatory Activity of a Novel Polysaccharide from Lepidium meyenii. J. Agric. Food Chem. 2016, 64, 1921-1931. [CrossRef] [PubMed]

128. Natella, F.; Maldini, M.; Leoni, G.; Scaccini, C. Glucosinolates Redox Activities: Can They Act as Antioxidants? Food Chem. 2014, 149, 226-232. [CrossRef] [PubMed]

129. Mithen, R. Glucosinolates-Biochemistry, Genetics and Biological Activity. Plant Growth Regul. 2001, 34, 91-103. [CrossRef]

130. Manici, L.M.; Lazzeri, L.; Palmieri, S. In Vitro Fungitoxic Activity of Some Glucosinolates and Their Enzyme-Derived Products toward Plant Pathogenic Fungi. J. Agric. Food Chem. 1997, 45, 2768-2773. [CrossRef]

131. Rubio, J.; Dang, H.; Gong, M.; Liu, X.; Chen, S.-L.; Gonzales, G.F. Aqueous and Hydroalcoholic Extracts of Black Maca (Lepidium meyenii) Improve Scopolamine-Induced Memory Impairment in Mice. Food Chem. Toxicol. 2007, 45, 1882-1890. [CrossRef]

132. Pino-Figueroa, A.; Nguyen, D.; Maher, T.J. Neuroprotective Effects of Lepidium meyenii (Maca): Lepidium meyenii Neuroprotective Effects. Ann. N. Y. Acad. Sci. 2010, 1199, 77-85. [CrossRef]

133. Rodríguez-Huamán, Á.; Casimiro-Gonzales, S.; Chávez-Pérez, J.A.; Gonzales-Arimborgo, C.; Cisneros-Fernández, R.; AguilarMendoza, L.Á.; Gonzales, G.F. Antioxidant and Neuroprotector Effect of Lepidium meyenii (Maca) Methanol Leaf Extract against 6-Hydroxy Dopamine (6-OHDA)-Induced Toxicity in PC12 Cells. Toxicol. Mech. Methods 2017, 27, 279-285. [CrossRef]

134. Ohta, Y.; Kawate, N.; Inaba, T.; Morii, H.; Takahashi, K.; Tamada, H. Feeding Hydroalcoholic Extract Powder of Lepidium meyenii (Maca) Enhances Testicular Gene Expression of 3ß-Hydroxysteroid Dehydrogenase in Rats. Andrologia 2017, 49. [CrossRef]

135. Vecera, R.; Orolin, J.; Skottová, N.; Kazdová, L.; Oliyarnik, O.; Ulrichová, J.; Simánek, V. The Influence of Maca (Lepidium meyenii) on Antioxidant Status, Lipid and Glucose Metabolism in Rat. Plant Foods Hum. Nutr. 2007, 62, 59-63. [CrossRef]

136. Qiu, C.; Zhu, T.; Lan, L.; Zeng, Q.; Du, Z. Analysis of Maceaene and Macamide Contents of Petroleum Ether Extract of Black, Yellow, and Purple Lepidium meyenii (Maca) and Their Antioxidant Effect on Diabetes Mellitus Rat Model. Braz. Arch. Biol. Technol. 2016, 59, 1-9. [CrossRef]

137. Yucra, S.; Gasco, M.; Rubio, J.; Nieto, J.; Gonzales, G.F. Effect of Different Fractions from Hydroalcoholic Extract of Black Maca (Lepidium meyenii) on Testicular Function in Adult Male Rats. Fertil. Steril. 2008, 89, 1461-1467. [CrossRef] [PubMed]

138. Meissner, H.O.; Kapczynski, W.; Mscisz, A.; Lutomski, J. Use of Gelatinized Maca (Lepidium Peruvianum) in Early Postmenopausal Women. Int. J. Biomed. Sci. 2005, 1, 33-45. [PubMed]

139. Dording, C.M.; Fisher, L.; Papakostas, G.; Farabaugh, A.; Sonawalla, S.; Fava, M.; Mischoulon, D. A Double-Blind, Randomized, Pilot Dose-Finding Study of Maca Root (L. Meyenii) for the Management of SSRI-Induced Sexual Dysfunction. CNS Neurosci. Ther. 2008, 14, 182-191. [CrossRef] [PubMed]

140. Stojanovska, L.; Law, C.; Lai, B.; Chung, T.; Nelson, K.; Day, S.; Apostolopoulos, V.; Haines, C. Maca Reduces Blood Pressure and Depression, in a Pilot Study in Postmenopausal Women. Climacteric 2015, 18, 69-78. [CrossRef]

141. Gonzales-Arimborgo, C.; Yupanqui, I.; Montero, E.; Alarcón-Yaquetto, D.E.; Zevallos-Concha, A.; Caballero, L.; Gasco, M.; Zhao, J.; Khan, I.A.; Gonzales, G.F. Acceptability, Safety, and Efficacy of Oral Administration of Extracts of Black or Red Maca (Lepidium meyenii) in Adult Human Subjects: A Randomized, Double-Blind, Placebo-Controlled Study. Pharmaceuticals 2016, 9, 49. [CrossRef]

142. Yang, Q.; Jin, W.; Lv, X.; Dai, P.; Ao, Y.; Wu, M.; Deng, W.; Yu, L. Effects of Macamides on Endurance Capacity and Anti-Fatigue Property in Prolonged Swimming Mice. Pharm. Biol. 2016, 54, 827-834. [CrossRef]

143. Zheng, Y.; Zhang, W.C.; Wu, Z.Y.; Fu, C.X.; Hui, A.L.; Gao, H.; Chen, P.P.; Du, B.; Zhang, H.W. Two Macamide Extracts Relieve Physical Fatigue by Attenuating Muscle Damage in Mice: Anti-Fatigue Activity of Two Macamide Extracts. J. Sci. Food Agric. 2019, 99, 1405-1412. [CrossRef] [PubMed]

144. Zha, R.; Ge, E.; Guo, L.; Gao, Q.; Lin, Q.; Zhou, W.; Jin, X.; Xie, W.; Yin, H.; Liu, T. A Newly Identified Polyunsaturated Macamide Alleviates Dextran Sulfate Sodium-Induced Colitis in Mice. Fitoterapia 2021, 152, 104916. [CrossRef] [PubMed] 
145. Gugnani, K.S.; Vu, N.; Rondón-Ortiz, A.N.; Böhlke, M.; Maher, T.J.; Pino-Figueroa, A.J. Neuroprotective Activity of Macamides on Manganese-Induced Mitochondrial Disruption in U-87 MG Glioblastoma Cells. Toxicol. Appl. Pharmacol. 2018, 340, 67-76. [CrossRef]

146. Clément, C.; Diaz Grados, D.A.; Avula, B.; Khan, I.A.; Mayer, A.C.; Ponce Aguirre, D.D.; Manrique, I.; Kreuzer, M. Influence of Colour Type and Previous Cultivation on Secondary Metabolites in Hypocotyls and Leaves of Maca (Lepidium meyenii Walpers). J. Sci. Food Agric. 2010, 90, 861-869. [CrossRef] [PubMed]

147. Chen, L.; Li, J.; Fan, L. The Nutritional Composition of Maca in Hypocotyls (Lepidium meyenii Walp.) Cultivated in Different Regions of China. J. Food Qual. 2017, 2017, e3749627. [CrossRef]

148. Bai, N.; He, K.; Roller, M.; Lai, C.S.; Bai, L.; Pan, M.H. Flavonolignans and Other Constituents from Lepidium meyenii with Activities in Anti-Inflammation and Human Cancer Cell Lines. J. Agric. Food Chem. 2015, 63, 2458-2463. [CrossRef]

149. Dini, I.; Tenore, G.C.; Dini, A. Glucosinolates from Maca (Lepidium meyenii). Biochem. Syst. Ecol. 2002, 30, 1087-1090. [CrossRef]

150. Li, G.; Ammermann, U.; Quirós, C.F. Glucosinolate Contents in Maca (Lepidium Peruvianum Chacón) Seeds, Sprouts, Mature Plants and Several Derived Commercial Products. Econ. Bot. 2001, 55, 255-262. [CrossRef]

151. Cui, B.; Zheng, B.L.; He, K.; Zheng, Q.Y. Imidazole Alkaloids from Lepidium meyenii. J. Nat. Prod. 2003, 66, 1101-1103. [CrossRef]

152. Zha, S.; Zhao, Q.; Chen, J.; Wang, L.; Zhang, G.; Zhang, H.; Zhao, B. Extraction, Purification and Antioxidant Activities of the Polysaccharides from Maca (Lepidium meyenii). Carbohydr. Polym. 2014, 111, 584-587. [CrossRef]

153. Loyer, J. Communicating Superfoods: A Case Study of Maca Packaging In Food and Communication: Proceedings of the Oxford Symposium on Food and Cookery 2015; McWilliams, M., Ed.; Prospect Books: London, UK, 2016; pp. 236-246. ISBN 978-1-909-248-49-6.

154. Rondán-Sanabria, G.G.; Finardi-Filho, F. Physical-Chemical and Functional Properties of Maca Root Starch (Lepidium meyenii Walpers). Food Chem. 2009, 114, 492-498. [CrossRef]

155. Zhang, L.; Li, G.; Wang, S.; Yao, W.; Zhu, F. Physicochemical Properties of Maca Starch. Food Chem. 2017, 218, 56-63. [CrossRef]

156. Lee, Y.K.; Chang, Y.H. Physicochemical and Antioxidant Properties of Methanol Extract from Maca (Lepidium meyenii Walp.) Leaves and Roots. Food Sci. Technol. 2019, 39, 278-286. [CrossRef]

157. Caba, Z.T. The Concept of Superfoods in Diet. In The Role of Alternative and Innovative Food Ingredients and Products in Consumer Wellness; Elsevier: Amsterdam, The Netherlands, 2019; pp. 73-101. [CrossRef]

158. Wolfe, D. Superfoods: The Food and Medicine of the Future; North Atlantic Books: Berkeley, CA, USA, 2009 ; ISBN 9781556437762.

159. Driessche, J.J.; van den Plat, J.; Mensink, R.P. Effects of Superfoods on Risk Factors of Metabolic Syndrome: A Systematic Review of Human Intervention Trials. Food Funct. 2018, 9, 1944-1966. [CrossRef]

160. Yan-Lin, S.; Lin-De, L.; Soon-Kwan, H. Eleutherococcus senticosus as a Crude Medicine: Review of Biological and Pharmacological Effects. JMPR 2011, 5, 5946-5952. [CrossRef]

161. Baczek, K.; Weglarz, Z.; Przybył, J. Accumulation of Biologically Active Compounds in the Rhizomes and Roots of Eleuthero (Eleutherococcus senticosus/Maxim. Et Rupr./Maxim.). Adv. Environ. Biol. 2011, 5, 325-328.

162. European Directorate for the Quality of Medicines \& Health Care. Eleutherococci radix. In European Pharmacopoeia, Monograph 01/2008:1419: Corrected 7.0; European Directorate for the Quality of Medicines \& Health Care: Strasburg, France, 2016.

163. Huang, L.; Zhao, H.; Huang, B.; Zheng, C.; Peng, W.; Qin, L. Acanthopanax senticosus: Review of Botany, Chemistry and Pharmacology. Pharm. Int. J. Pharm. Sci. 2011, 66, 83-97. [CrossRef]

164. Bleakney, T.L. Deconstructing an Adaptogen: Eleutherococcus senticosus. Holist. Nurs. Pract. 2008, 22, 220-224. [CrossRef] [PubMed]

165. Bokelmann, J.M. 43-Eleuthero/Siberian Ginseng (Eleutherococcus senticosus / Acanthopanax senticosus): Root. In Medicinal Herbs in Primary Care; Bokelmann, J.M., Ed.; Elsevier: Amsterdam, The Netherlands, 2022; pp. 327-333. ISBN 9780323846769.

166. Dowling, E.A.; Redondo, D.R.; Branch, J.D.; Jones, S.; McNabb, G.; Williams, M.H. Effect of Eleutherococcus senticosus on Submaximal and Maximal Exercise Performance. Med. Sci. Sports Exerc. 1996, 28, 482-489. [CrossRef] [PubMed]

167. Eschbach, L.C.; Webster, M.J.; Boyd, J.C.; McArthur, P.D.; Evetovich, T.K. The Effect of Siberian Ginseng (Eleutherococcus senticosus) on Substrate Utilization and Performance during Prolonged Cycling. Int. J. Sport Nutr. Exerc. Metab. 2000, 10, 444-451. [CrossRef] [PubMed]

168. Cicero, A.F.G.; Derosa, G.; Brillante, R.; Bernardi, R.; Nascetti, S.; Gaddi, A. Effects of Siberian Ginseng (Eleutherococcus senticosus Maxim.) on Elderly Quality of Life: A Randomized Clinical Trial. Arch. Gerontol. Geriatr. 2004, 38, 69-73. [CrossRef]

169. Shen, M.L.; Zhai, S.K.; Chen, H.L.; Luo, Y.D.; Tu, G.R.; Ou, D.W. Immunomopharmacological Effects of Polysaccharides from Acanthopanax senticosus on Experimental Animals. Int. J. Immunopharmacol. 1991, 13, 549-554. [CrossRef]

170. Augustin, J.M.; Kuzina, V.; Andersen, S.B.; Bak, S. Molecular Activities, Biosynthesis and Evolution of Triterpenoid Saponins. Phytochemistry 2011, 72, 435-457. [CrossRef]

171. Kimura, Y.; Sumiyoshi, M. Effects of Various Eleutherococcus senticosus Cortex on Swimming Time, Natural Killer Activity and Corticosterone Level in Forced Swimming Stressed Mice. J. Ethnopharmacol. 2004, 95, 447-453. [CrossRef]

172. Ahn, J.; Um, M.Y.; Lee, H.; Jung, C.H.; Heo, S.H.; Ha, T.Y. Eleutheroside E, An Active Component of Eleutherococcus senticosus, Ameliorates Insulin Resistance in Type 2 Diabetic Db/Db Mice. Evid.-Based Complement. Altern. Med. 2013, 2013, e934183. [CrossRef]

173. Soine, T.O. Naturally Occurring Coumarins and Related Physiological Activities. J. Pharm. Sci. 1964, 53, 231-264. [CrossRef]

174. Fang, J.N.; Proksch, A.; Wagner, H. Immunologically Active Polysaccharides of Acanthopanax senticosus. Phytochemistry 1985, 24, 2619-2622. [CrossRef] 
175. Załuski, D.; Olech, M.; Galanty, A.; Verpoorte, R.; Kuźniewski, R.; Nowak, R.; Bogucka-Kocka, A. Phytochemical Content and Pharma-Nutrition Study on Eleutherococcus senticosus Fruits Intractum. Oxid. Med. Cell. Longev. 2016, 2016, e9270691. [CrossRef] [PubMed]

176. Asano, K.; Takahashi, T.; Miyashita, M.; Matsuzaka, A.; Muramatsu, S.; Kuboyama, M.; Kugo, H.; Imai, J. Effect of Eleutheroccocus Senticosus Extract on Human Physical Working Capacity. Planta Med. 1986, 52, 175-177. [CrossRef]

177. Kuo, J.; Chen, K.W.C.; Cheng, I.S.; Tsai, P.H.; Lu, Y.J.; Lee, N.Y. The Effect of Eight Weeks of Supplementation with Eleutherococcus senticosus on Endurance Capacity and Metabolism in Human. Chin. J. Physiol. 2010, 53, 105-111. [CrossRef] [PubMed]

178. Yamauchi, Y.; Ge, Y.W.; Yoshimatsu, K.; Komatsu, K.; Kuboyama, T.; Yang, X.; Tohda, C. Memory Enhancement by Oral Administration of Extract of Eleutherococcus senticosus Leaves and Active Compounds Transferred in the Brain. Nutrients 2019, 11, 1142. [CrossRef]

179. Lee, D.; Park, J.; Yoon, J.; Kim, M.; Choi, H.; Kim, H. Neuroprotective Effects of Eleutherococcus senticosus Bark on Transient Global Cerebral Ischemia in Rats. J. Ethnopharmacol. 2012, 139, 6-11. [CrossRef]

180. Ahmed, S.; Moni, D.A.; Sonawane, K.D.; Paek, K.Y.; Shohael, A.M. A Comprehensive in Silico Exploration of Pharmacological Properties, Bioactivities and COX-2 Inhibitory Potential of Eleutheroside B from Eleutherococcus senticosus (Rupr. \& Maxim.) Maxim. J. Biomol. Struct. Dyn. 2021, 39, 6553-6566. [CrossRef] [PubMed]

181. Tan, J.; Luo, J.; Meng, C.; Jiang, N.; Cao, J.; Zhao, J. Syringin Exerts Neuroprotective Effects in a Rat Model of Cerebral Ischemia through the FOXO3a/NF-KB Pathway. Int. Immunopharmacol. 2021, 90, 107268. [CrossRef] [PubMed]

182. Zhang, H.; Gu, H.; Zhao, Q.J.Y.; Li, H.; Shen, S.; Liu, X.; Wang, G.; Shi, Q. Syringin Protects against Colitis by Ameliorating Inflammation. Arch. Biochem. Biophys. 2020, 680, 108242. [CrossRef] [PubMed]

183. Liu, J.; Zhang, Z.; Guo, Q.; Dong, Y.; Zhao, Q.; Ma, X. Syringin Prevents Bone Loss in Ovariectomized Mice via TRAF6 Mediated Inhibition of NF-KB and Stimulation of PI3K/AKT. Phytomedicine 2018, 42, 43-50. [CrossRef] [PubMed]

184. Huang, L.Z.; Wei, L.; Zhao, H.F.; Huang, B.-K.; Rahman, K.; Qin, L.-P. The Effect of Eleutheroside E on Behavioral Alterations in Murine Sleep Deprivation Stress Model. Eur. J. Pharmacol. 2011, 658, 150-155. [CrossRef] [PubMed]

185. Wang, S.; Yang, X. Eleutheroside E Decreases Oxidative Stress and NF-KB Activation and Reprograms the Metabolic Response against Hypoxia-Reoxygenation Injury in H9c2 Cells. Int. Immunopharmacol. 2020, 84, 106513. [CrossRef]

186. Ovodov, Y.S.; Frolova, G.M.; Nefedova, M.Y.; Elyakov, G.B. The Glycosides of Eleutherococcus senticosus II. The Structure of Eleutherosides A, B1, C, and D. Chem. Nat. Compd. 1967, 3, 53-54. [CrossRef]

187. Kang, J.S.; Linh, P.T.; Cai, X.F.; Kim, H.S.; Lee, J.J.; Kim, Y.H. Quantitative Determination of Eleutheroside B and E From Acanthopanax Species by High Performance Liquid Chromatography. Arch. Pharm. Res. 2001, 24, 407-411. [CrossRef]

188. Apers, S.; Naessens, T.; Van Miert, S.; Pieters, L.; Vlietinck, A. Quality Control of Roots of Eleutherococcus senticosus by HPLC. Phytochem. Anal. 2005, 16, 55-60. [CrossRef] [PubMed]

189. Yat, P.N.; Arnason, J.T.; Awang, D.V.C. An Improved Extraction Procedure for the Rapid, Quantitative High-Performance Liquid Chromatographic Estimation of the Main Eleutherosides (b and e) in Eleutherococcus senticosus (Eleuthero). Phytochem. Anal. 1998, 9, 291-295. [CrossRef]

190. Li, X.C.; Barnes, D.L.; Khan, I.A. A New Lignan Glycoside from Eleutherococcus senticosus. Planta Med. 2001, 67, 776-778. [CrossRef] [PubMed]

191. Hikino, H.; Takahashi, M.; Otake, K.; Konno, C. Isolation and Hypoglycemic Activity of Eleutherans A, B, C, D, E, F, and G: Glycans of Eleutherococcus senticosus Roots. J. Nat. Prod. 1986, 49, 293-297. [CrossRef] [PubMed]

192. Park, S.Y.; Chang, S.Y.; Yook, C.S.; Nohara, T. New 3,4-Seco-Lupane-Type Triterpene Glycosides from Acanthopanax senticosus Forma Inermis. J. Nat. Prod. 2000, 63, 1630-1633. [CrossRef]

193. Lee, S.; Shin, D.S.; Oh, K.B.; Shin, K.H. Antibacterial Compounds from the Leaves of Acanthopanax senticosus. Arch. Pharm. Res. 2003, 26, 40-42. [CrossRef]

194. Suprunov, N.I.; Dzizenko, S.N. (-)-Sesamin from Eleutherococcus senticosus. Chem. Nat. Compd. 1971, 7, 502. [CrossRef]

195. Choi, K. Botanical Characteristics, Pharmacological Effects and Medicinal Components of Korean Panax ginseng C A Meyer. Acta Pharmacol. Sin. 2008, 29, 1109-1118. [CrossRef]

196. Zhuo, D. Preventive Geriatrics: An Overview from Traditional Chinese Medicine. Am. J. Chin. Med. 1982, 10, 32-39. [CrossRef] [PubMed]

197. Coon, J.T.; Ernst, E. Panax ginseng: A Systematic Review of Adverse Effects and Drug Interactions. Drug Saf. 2002, 25, 323-344. [CrossRef]

198. Nocerino, E.; Amato, M.; Izzo, A.A. The Aphrodisiac and Adaptogenic Properties of Ginseng. Fitoterapia 2000, 71, S1-S5. [CrossRef]

199. European Directorate for the Quality of Medicines \& Health Care. Ginseng radix. In European Pharmacopoeia, Monograph 07/2019:1523; European Directorate for the Quality of Medicines \& Health Care: Strasburg, France, 2019.

200. Mancuso, C.; Santangelo, R. Panax ginseng and Panax Quinquefolius: From Pharmacology to Toxicology. Food Chem. Toxicol. 2017, 107, 362-372. [CrossRef] [PubMed]

201. Patel, S.; Rauf, A. Adaptogenic Herb Ginseng (Panax) as Medical Food: Status Quo and Future Prospects. Biomed. Pharmacother. 2017, 85, 120-127. [CrossRef] [PubMed]

202. Kiefer, D.S.; Pantuso, T. Panax ginseng. AFP 2003, 68, 1539-1542. 
203. Kim, S.H.; Park, K.S. Effects of Panax ginseng Extract on Lipid Metabolism in Humans. Pharmacol. Res. 2003, 48, 511-513. [CrossRef]

204. Engels, H.-J.; Said, J.M.; Wirth, J.C. Failure of Chronic Ginseng Supplementation to Affect Work Performance and Energy Metabolism in Healthy Adult Females. Nutr. Res. 1996, 16, 1295-1305. [CrossRef]

205. Zarabi, L.; Arazi, H.; Izadi, M. The Effects of Panax ginseng Supplementation on Growth Hormone, Cortisol and Lactate Response to High-Intensity Resistance Exercise. Biomed. Hum. Kinet. 2018, 10, 8-14. [CrossRef]

206. Kim, H.G.; Cho, J.H.; Yoo, S.R.; Lee, J.S.; Han, J.M.; Lee, N.H.; Son, C.G. Antifatigue Effects of Panax ginseng CA Meyer: A Randomised, Double-Blind, Placebo-Controlled Trial. PLoS ONE 2013, 8, E61271.

207. Christensen, L.P. Chapter 1 Ginsenosides: Chemistry, Biosynthesis, Analysis, and Potential Health Effects. In Advances in Food and Nutrition Research; Academic Press: Cambridge, MA, USA, 2008; Volume 55, pp. 1-99. ISBN 10434526.

208. Leung, K.W.; Wong, A.S.T. Pharmacology of Ginsenosides: A Literature Review. Chin. Med. 2010, 5, 20. [CrossRef]

209. Lee, J.H.; Ko, M.J.; Chung, M.S. Subcritical Water Extraction of Bioactive Components from Red Ginseng (Panax ginseng C.A. Meyer). J. Supercrit. Fluids 2018, 133, 177-183. [CrossRef]

210. Park, J.D.; Rhee, D.K.; Lee, Y.H. Biological Activities and Chemistry of Saponins from Panax ginseng C. A. Meyer. Phytochem. Rev. 2005, 4, 159-175. [CrossRef]

211. Rausch, W.D.; Liu, S.; Gille, G.; Radad, K. Neuroprotective Effects of Ginsenosides. Acta Neurobiol. Exp. 2006, 66, $369-375$.

212. Smith, I.; Williamson, E.M.; Putnam, S.; Farrimond, J.; Whalley, B.J. Effects and Mechanisms of Ginseng and Ginsenosides on Cognition. Nutr. Rev. 2014, 72, 319-333. [CrossRef] [PubMed]

213. Nag, S.; Qin, J.; Wang, W.; Wang, M.H.; Wang, H.; Zhang, R. Ginsenosides as Anticancer Agents: In Vitro and in Vivo Activities, Structure-Activity Relationships, and Molecular Mechanisms of Action. Front. Pharmacol. 2012, 3, 25. [CrossRef] [PubMed]

214. Qi, L.W.; Wang, C.Z.; Yuan, C.S. Ginsenosides from American Ginseng: Chemical and Pharmacological Diversity. Phytochemistry 2011, 72, 689-699. [CrossRef] [PubMed]

215. Yang, W.; Qiao, X.; Li, K.; Fan, J.; Bo, T.; Guo, D.; Ye, M. Identification and Differentiation of Panax ginseng, Panax Quinquefolium, and Panax Notoginseng by Monitoring Multiple Diagnostic Chemical Markers. Acta Pharm. Sin. B 2016, 6, 568-575. [CrossRef]

216. Du, Z.; Li, J.; Zhang, X.; Pei, J.; Huang, L. An Integrated LC-MS-Based Strategy for the Quality Assessment and Discrimination of Three Panax Species. Molecules 2018, 23, 2988. [CrossRef]

217. Reay, J.L.; Scholey, A.B.; Kennedy, D.O. Panax ginseng (G115) Improves Aspects of Working Memory Performance and Subjective Ratings of Calmness in Healthy Young Adults. Hum. Psychopharmacol. Clin. Exp. 2010, 25, 462-471. [CrossRef]

218. Bhattacharjee, I.; Bandyopadhyay, A. Effects of Acute Supplementation of Panax ginseng on Endurance Performance in Healthy Adult Males of Kolkata, India. Int. J. Clin. Exp. Physiol. 2020, 7, 63-68. [CrossRef]

219. Etemadifar, M.; Sayahi, F.; Abtahi, S.H.; Shemshaki, H.; Dorooshi, G.-A.; Goodarzi, M.; Akbari, M.; Fereidan-Esfahani, M. Ginseng in the Treatment of Fatigue in Multiple Sclerosis: A Randomized, Placebo-Controlled, Double-Blind Pilot Study. Int. J. Neurosci. 2013, 123, 480-486. [CrossRef]

220. Lee, S.A.; Kang, S.G.; Lee, H.J.; Jung, K.Y.; Kim, L. Effect of Korean Red Ginseng on Sleep: A Randomized, Placebo-Controlled Trial. Sleep Med. Psychophysiol. 2010, 17, 85-90.

221. Attele, A.S.; Zhou, Y.-P.; Xie, J.T.; Wu, J.A.; Zhang, L.; Dey, L.; Pugh, W.; Rue, P.A.; Polonsky, K.S.; Yuan, C.-S. Antidiabetic Effects of Panax ginseng Berry Extract and the Identification of an Effective Component. Diabetes 2002, 51, 1851-1858. [CrossRef]

222. Kim, J.Y.; Germolec, D.R.; Luster, M.I. Panax ginseng as a Potential Immunomodulator: Studies in Mice. Immunopharmacol. Immunotoxicol. 1990, 12, 257-276. [CrossRef] [PubMed]

223. Ban, J.Y.; Kang, S.W.; Lee, J.S.; Chung, J.-H.; Ko, Y.G.; Choi, H.S. Korean Red Ginseng Protects against Neuronal Damage Induced by Transient Focal Ischemia in Rats. Exp. Ther. Med. 2012, 3, 693-698. [CrossRef] [PubMed]

224. Lim, K.H.; Cho, J.Y.; Kim, B.; Bae, B.-S.; Kim, J.-H. Red Ginseng (Panax ginseng) Decreases Isoproterenol-Induced Cardiac Injury via Antioxidant Properties in Porcine. J. Med. Food 2014, 17, 111-118. [CrossRef] [PubMed]

225. Kim, Y.S.; Kim, Y.H.; Noh, J.R.; Cho, E.S.; Park, J.H.; Son, H.Y. Protective Effect of Korean Red Ginseng against Aflatoxin B1-Induced Hepatotoxicity in Rat. J. Ginseng Res. 2011, 35, 243-249. [CrossRef]

226. Abdelfattah-Hassan, A.; Shalaby, S.I.; Khater, S.I.; El-Shetry, E.S.; Abd El Fadil, H.; Elsayed, S.A. Panax ginseng Is Superior to Vitamin E as a Hepatoprotector against Cyclophosphamide-Induced Liver Damage. Complement. Ther. Med. 2019, 46, 95-102. [CrossRef]

227. Han, Y.; Wang, T.; Li, C.; Wang, Z.; Zhao, Y.; He, J.; Fu, L.; Han, B. Ginsenoside Rg3 Exerts a Neuroprotective Effect in Rotenone-Induced Parkinson's Disease Mice via Its Anti-Oxidative Properties. Eur. J. Pharmacol. 2021, 909, 174413. [CrossRef]

228. Sun, J.; Wang, R.; Chao, T.; Peng, J.; Wang, C.; Chen, K. Ginsenoside Re Inhibits Myocardial Fibrosis by Regulating MiR489/Myd88/NF-KB Pathway. J. Ginseng Res. 2021, S1226845321001688. [CrossRef]

229. Gu, D.; Yi, H.; Jiang, K.; Fakhar, S.H.; Shi, J.; He, Y.; Liu, B.; Guo, Y.; Fan, X.; Li, S. Transcriptome Analysis Reveals the Efficacy of Ginsenoside-Rg1 in the Treatment of Nonalcoholic Fatty Liver Disease. Life Sci. 2021, 267, 118986. [CrossRef]

230. Cui, J.; Shan, R.; Cao, Y.; Zhou, Y.; Liu, C.; Fan, Y. Protective Effects of Ginsenoside Rg2 against Memory Impairment and Neuronal Death Induced by A $\beta 25-35$ in Rats. J. Ethnopharmacol. 2021, 266, 113466. [CrossRef]

231. Mu, Q.; Zuo, J.; Zhao, D.; Zhou, X.; Hua, J.; Bai, Y.; Mo, F.; Fang, X.; Fu, M.; Gao, S. Ginsenoside Rg3 Reduces Body Weight by Regulating Fat Content and Browning in Obese Mice. J. Tradit. Chin. Med. Sci. 2021, 8, 65-71. [CrossRef] 
232. Yang, Z.; Yu, Y.; Sun, N.; Zhou, L.; Zhang, D.; Chen, H.; Miao, W.; Gao, W.; Zhang, C.; Liu, C.; et al. Ginsenosides Rc, as a Novel SIRT6 Activator, Protects Mice against High Fat Diet Induced NAFLD. J. Ginseng Res. 2020, S1226845320301160. [CrossRef]

233. Zhang, Y.; Ji, H.; Qiao, O.; Li, Z.; Pecoraro, L.; Zhang, X.; Han, X.; Wang, W.; Zhang, X.; Man, S.; et al. Nanoparticle Conjugation of Ginsenoside Rb3 Inhibits Myocardial Fibrosis by Regulating PPAR $\alpha$ Pathway. Biomed. Pharmacother. 2021, 139, 111630. [CrossRef] [PubMed]

234. Jihee, H.; Gwon, D.; Jang, C. Ginsenoside Rg1 Suppresses Cancer Cell Proliferation through Perturbing Mitotic Progression. J. Ginseng Res. 2021. [CrossRef]

235. Hu, C.; Yang, L.; Wang, Y.; Zhou, S.; Luo, J.; Gu, Y. Ginsenoside Rh2 Reduces M6A RNA Methylation in Cancer via the KIF26B-SRF Positive Feedback Loop. J. Ginseng Res. 2021, 45, 734-743. [CrossRef]

236. Ke, C.; Peng, Y.; Yuan, Z.; Cai, J. Ginsenoside Rb1 Protected PC12 Cells from A $325-35-$ Induced Cytotoxicity via PPAR $\gamma$ Activation and Cholesterol Reduction. Eur. J. Pharmacol. 2021, 893, 173835. [CrossRef]

237. Lu, M.L.; Wang, J.; Sun, Y.; Li, C.; Sun, T.R.; Hou, X.W.; Wang, H.-X. Ginsenoside Rg1 Attenuates Mechanical Stress-Induced Cardiac Injury via Calcium Sensing Receptor-Related Pathway. J. Ginseng Res. 2021, 45, 683-694. [CrossRef]

238. Besso, H.; Kasai, R.; Saruwatari, Y.; Fuwa, T.; Tanaka, O. Ginsenoside-Ra1 and Ginsenoside-Ra2, New Dammarane-Saponins of Ginseng Roots. Chem. Pharm. Bull. 1982, 30, 2380-2385. [CrossRef]

239. Kim, D.-S.; Chang, Y.-J.; Zedk, U.; Zhao, P.; Liu, Y.-Q.; Yang, C.-R. Dammarane Saponins from Panax ginseng. Phytochemistry 1995, 40, 1493-1497. [CrossRef]

240. Ma, X.Q.; Liang, X.-M.; Xu, Q.; Zhang, X.-Z.; Xiao, H.-B. Identification of Ginsenosides in Roots of Panax ginseng by HPLCAPCI/MS. Phytochem. Anal. 2005, 16, 181-187. [CrossRef]

241. Fuzzati, N.; Gabetta, B.; Jayakar, K.; Pace, R.; Peterlongo, F. Liquid Chromatography-Electrospray Mass Spectrometric Identification of Ginsenosides in Panax ginseng Roots. J. Chromatogr. A 1999, 854, 69-79. [CrossRef]

242. Samukawa, K.I.; Yamashita, H.; Matsuda, H.; Kubo, M. Simultaneous Analysis of Saponins in Ginseng Radix by High Performance Liquid Chromatography. Chem. Pharm. Bull. 1995, 43, 137-141. [CrossRef]

243. Sun, B.S.; Gu, L.J.; Fang, Z.M.; Wang, C.; Wang, Z.; Lee, M.-R.; Li, Z.; Li, J.J.; Sung, C.-K. Simultaneous Quantification of 19 Ginsenosides in Black Ginseng Developed from Panax ginseng by HPLC-ELSD. J. Pharm. Biomed. Anal. 2009, 50, 15-22. [CrossRef] [PubMed]

244. Sanada, S.; Kondo, N.; Shoji, J.; Tanaka, O.; Shibata, S. Studies on the Saponins of Ginseng. I. Studies on the saponins of ginseng. I. Structure of ginseng-R0, Rb1, Rb2, RC and Rd. Chem. Pharm. Bull. 1974, 22, 421-428. [CrossRef]

245. Yahara, S.; Tanaka, O.; Komori, T. Saponins of the Leaves of Panax ginseng C. A. Meyer. Chem. Pharm. Bull. 1976, $24,2204-2208$. [CrossRef]

246. Sanada, S.; Kondo, N.; Shoji, J.; Tanaka, O.; Shibata, S. Studies on the Saponins of Ginseng. II. Structures of Ginsenoside-Re, -Rf and -Rg2. Chem. Pharm. Bull. 1974, 22, 2407-2412. [CrossRef]

247. Zhang, H.; Lu, Z.; Tan, G.T.; Qiu, S.; Farnsworth, N.R.; Pezzuto, J.M.; Fong, H.H.S. Polyacetyleneginsenoside-Ro, a Novel Triterpene Saponin from Panax ginseng. Tetrahedron Lett. 2002, 43, 973-977. [CrossRef]

248. Dou, D.Q.; Chen, Y.J.; Liang, L.H.; Pang, F.G.; Shimizu, N.; Takeda, T. Six New Dammarane-Type Triterpene Saponins from the Leaves of Panax ginseng. Chem. Pharm. Bull. 2001, 49, 442-446. [CrossRef]

249. Park, I.H.; Kim, N.Y.; Han, S.B.; Kim, J.M.; Kwon, S.W.; Kim, H.J.; Park, M.K.; Park, J.H. Three New Dammarane Glycosides from Heat Processed Ginseng. Arch. Pharm. Res. 2002, 25, 428. [CrossRef]

250. Park, I.H.; Han, S.B.; Kim, J.M.; Piao, L.; Kwon, S.W.; Kim, N.Y.; Kang, T.L.; Park, M.K.; Park, J.H. Four New Acetylated Ginsenosides from Processed Ginseng (Sun Ginseng). Arch. Pharm. Res. 2002, 25, 837. [CrossRef]

251. Qiu, F.; Ma, Z.-Z.; Xu, S.-X.; Yao, X.-S.; Che, C.-T.; Chen, Y.-J. A Pair of 24-Hydroperoxyl Epimeric Dammarane Saponins from Flower-Buds of Panax ginseng. J. Asian Nat. Prod. Res. 2001, 3, 235-240. [CrossRef]

252. Uvarova, N.I.; Makhan'kova, V.V.; Malinovskaya, G.V.; Samoshina, N.F.; Atopkina, L.N.; Likhatskaya, G.N.; Kim, N.Y.; Anisimov, M.M.; Elyakov, G.B. Triterpene Glycosides from Wild and Cultivated Ginseng Occurring in Maritime Territory: Chemical Characterization, Comparative Quantitative Analysis, and Biological Activity Study. Pharm. Chem. J. 2000, 34, 122-129. [CrossRef]

253. Lee, D.Y.; Cha, B.J.; Lee, Y.S.; Kim, G.S.; Noh, H.J.; Kim, S.Y.; Kang, H.C.; Kim, J.H.; Baek, N.I. The Potential of Minor Ginsenosides Isolated from the Leaves of Panax ginseng as Inhibitors of Melanogenesis. Int. J. Mol. Sci. 2015, 16, 1677-1690. [CrossRef]

254. Cho, K.; Song, S.B.; Tung, N.H.; Kim, K.E.; Kim, Y.H. Inhibition of TNF- $\alpha$-Mediated NF-KB Transcriptional Activity by Dammarane-Type Ginsenosides from Steamed Flower Buds of Panax ginseng in HepG2 and SK-Hep1 Cells. Biomol. Ther. 2014, 22, 55-61. [CrossRef] [PubMed]

255. Li, K.K.; Xu, F.; Li, S.S.; Cao, G.Y.; Gong, X.-J. Cytotoxic Epimeric Ginsenosides from the Flower Buds of Panax ginseng. Steroids 2019, 143, 1-5. [CrossRef]

256. Samuel, A.D.; Tit, D.M.; Melinte, C.E.; Iovan, C.; Purza, L.; Gitea, M.; Bungau, S. Enzymological and Physicochemical Evaluation of the Effects of Soil Management Practices. Rev. Chim. 2017, 68, 2243-2247. [CrossRef]

257. Bungau, S.; Behl, T.; Aleya, L.; Bourgeade, P.; Aloui-Sossé, B.; Purza, A.L.; Abid, A.; Samuel, A.D. Expatiating the Impact of Anthropogenic Aspects and Climatic Factors on Long-Term Soil Monitoring and Management. Environ. Sci. Pollut. Res. 2021, 28, 30528-30550. [CrossRef] [PubMed]

258. Geszprych, A.; Weglarz, Z. Accumulation of Biologically Active Compounds in the Seeds of Rhaponticum carthamoides (Willd.) Iljin Cultivated in Poland. Folia Hortic. 2002, 14, 195-199. 
259. Kizelsztein, P.; Govorko, D.; Komarnytsky, S.; Evans, A.; Wang, Z.; Cefalu, W.T.; Raskin, I. 20-Hydroxyecdysone Decreases Weight and Hyperglycemia in a Diet-Induced Obesity Mice Model. Am. J. Physiol. Endocrinol. Metab. 2009, 296, E433-E439. [CrossRef] [PubMed]

260. Marschall, M.J.M.; Ringseis, R.; Gessner, D.K.; Grundmann, S.M.; Most, E.; Wen, G.; Maheshwari, G.; Zorn, H.; Eder, K. Effect of Ecdysterone on the Hepatic Transcriptome and Lipid Metabolism in Lean and Obese Zucker Rats. Int. J. Mol. Sci. 2021, $22,5241$. [CrossRef] [PubMed] 